\title{
Seismic Vulnerability Assessment Methodologies for Roadway Assets and Networks: A State-of-the-Art Review
}

\author{
Ahmad Mohamad El-Maissi ${ }^{1}$, Sotirios A. Argyroudis ${ }^{2, *}$ and Fadzli Mohamed Nazri ${ }^{1}$ (D) \\ 1 School of Civil Engineering, Engineering Campus, Universiti Sains Malaysia, Penang 14300, Malaysia; \\ missi_1993@hotmail.com (A.M.E.-M.); cefmn@usm.my (F.M.N.) \\ 2 Department of Civil and Environmental Engineering, College of Engineering, Design and Physical Sciences, \\ Brunel University, London UB8 3PH, UK \\ * Correspondence: Sotirios.Argyroudis@brunel.ac.uk
}

Citation: El-Maissi, A.M.;

Argyroudis, S.A.; Nazri, F.M. Seismic Vulnerability Assessment Methodologies for Roadway Assets and Networks: A State-of-the-Art Review. Sustainability 2021, 13, 61. https://dx.doi.org/10.3390/ su13010061

Received: 23 November 2020 Accepted: 21 December 2020 Published: 23 December 2020

Publisher's Note: MDPI stays neutral with regard to jurisdictional claims in published maps and institutional affiliations.

Copyright: () 2020 by the authors. Licensee MDPI, Basel, Switzerland. This article is an open access article distributed under the terms and conditions of the Creative Commons Attribution (CC BY) license (https: / / creativecommons.org/ licenses/by/4.0/).

\begin{abstract}
Road networks are considered as one of the most important transport infrastructure systems, since they attain the economic and social prosperity of modern societies. For this reason, it is vital to improve the resiliency of road networks in order to function normally under daily stressors and recover quickly after natural disasters such as an earthquake event. In the last decades, vulnerability assessment studies for road networks and their assets gained great attention among the research community. This literature review includes a brief introduction about seismic vulnerability assessment, followed by the roadway assets damage and their damage states, and then the main typologies for the vulnerability assessment of roadway assets. Moreover, it focuses on available assessment methods, which were proposed to quantify the vulnerability of road networks and its assets. These methods are divided into two main categories, physical and traffic-based approaches. Methods based on fragility functions and vulnerability indexes were investigated in physical approach for roadways and its assets. On the other hand, accessibility and link importance index were explored in traffic-based approach for road networks. This paper reviews and comments the most common vulnerability assessment methods for road networks and its assets and points out their advantages and disadvantages. The main gaps and needs are identified and recommendations for future studies are provided.
\end{abstract}

Keywords: vulnerability assessment; road network fragility functions; vulnerability index; accessibility index; link importance index; resilient infrastructure; cities disaster risk reduction

\section{Introduction}

Infrastructure is considered the backbone of our society and economy; it plays a crucial role in attaining the economic and social prosperity and sustainability of our world. Transport systems are essential critical infrastructure and play a crucial role in maintaining national security and supporting the recovery of any country during and/or after natural disasters. Nevertheless, earthquakes are considered as one of the most destructive geophysical disasters that might affect and paralyze transport systems [1].

Road networks are one of the main forms of transport infrastructure that contribute to mobility and accessibility for users. According to the World Bank, about $80 \%$ of freight and passenger movements occur on road networks. In addition to that, the annual passenger traffic on road networks will increase by $50 \%$ in the near future, and an additional 1.2 billion cars will be using road networks by 2050 [2]. Yet, road networks as any other transportation infrastructure are exposed and could be vulnerable to various natural hazard incidents. Koks et al. [3] investigated the risk and exposure for multihazards on different assets of road and railway infrastructure by studying the global expected annual damages (EAD) and exposures (EAE). The results showed that $27 \%$ of this infrastructure is subject to at least one hazard for a return period of 250 years, while, with respect to EAE, $0.5 \%$ of global infrastructure is endangered by multihazards. Direct damage for transport infrastructures 
exposed to multi-hazards is estimated to be between 3.1 to 22 billion USD globally; in particular, earthquakes result in $7.3 \%$ of the overall global EAD.

Due to all urgent risks, many countries have developed and improved measures to reduce the risk and to make cities and critical infrastructure more resilient [4,5]. Moreover, the United Nations adapted a strategic plan to implement the 2030 agenda for sustainable development goals (SDGs). One of the main goals in SDGs is making sustainable cities and human settlements and enhancing their resiliency against natural hazards. In particular, SDG9 and SDG11 mainly focus on building resilient infrastructure by promoting public and private investments and making human settlements inclusive, safe, and sustainable, to conduct a risk reduction plan that will save lives, reduce losses, and strengthen the resilience of cities. Achieving SDG9 and SDG11 will impact other SDGs. For example, decreasing the risk will result in low damage and loss of livelihood that will reduce poverty, as per SDG1 [6].

Moreover, the Transportation Research Board (TRB) policy works on achieving twelve basic goals that address critical issues for transportation. One of the main goals focuses on building more resilient and secure infrastructure against natural hazards. This goal, which is represented in the fourth topic of TRB report "Critical Issues in Transportation 2019", concentrates on endangered transport infrastructures facing natural hazards. TRB is concerned about rising risks resulting from natural hazards that threatens all transport systems. In this respect, policies and strategies should be extended to increase the resiliency and sustainability of critical transport infrastructure [7].

Past earthquake incidents have proven that the road network and its assets are vulnerable, while damage to the road network can affect the transportation of people and goods [8]. The destruction of roads can obstruct emergency vehicles and directly affect the rescue and aid emergency activities in the affected region, resulting in considerable economic, social, and livelihood losses for the community [6]. Furthermore, earthquake disasters can cause direct impacts on the structures of road networks, which involve both life-safety issues and repair/replacement losses. Additionally, this destruction results in long term and indirect economic losses on nations, by affecting tourism, trade, and/or other industries. A common classification of economic impact includes direct economic effects (repair/replacement costs of the damaged infrastructure) and direct consequential economic effects (linked to the disruption of the transport infrastructure and its cost on road users, such as road delays, fuel carbon emissions, and accident costs), and indirect consequential economic effects (usually influence rural regions, which mainly depend on transport activities in their daily life), as per Winter et al. [9]. Thus, these impacts are mostly influenced by the functionality of the transport network rather than the earthquake incident itself. Consequently, local business and tourism sectors in these regions will be negatively affected because reduction of accessibility will adversely decrease the profits and viability in these sectors in the short and long term $[9,10]$.

Representative examples of disruptive earthquakes that have caused failure to transport infrastructure are given in Table 1 . These events led to improvements in the seismic design and risk management in each country and in some cases internationally.

Looking at this evidence gives rise to the importance of assessing the seismic performance of road networks. The possible loss associated with potential seismic events can be estimated through a seismic vulnerability assessment of road networks and their assets. In this respect, a seismic vulnerability assessment of road networks is an important step toward improvement of infrastructure resilience and considerable enhancement of emergency accessibility through the application of suitable and efficient mitigation measures for emergencies [36,37]. 
Table 1. Examples of disruptive earthquakes that have caused failure to transport infrastructure.

\begin{tabular}{|c|c|c|}
\hline Earthquake Event and Losses & Impact & References \\
\hline $\begin{array}{l}\text { Loma Prieta (USA), } 1989, \mathrm{M}=7.1 \\
\text { It is considered among the most destructive and costly earthquakes } \\
\text { in the history of United States of America (USA), accounted for } \\
\text { approximately in } \$ 1.8 \text { billion in damages for road networks and } \$ 300 \\
\text { million in restoration cost for bridges. Various closures occurred at } \\
\text { multiple roads, accumulating } 65 \text { blockages related to direct damages } \\
\text { and } 85 \text { blockages related to indirect damages. }\end{array}$ & $\begin{array}{l}\text { Traffic disruption } \\
\text { Infrastructure damages } \\
\text { Possible safety concern } \\
\text { Economic costs } \\
\text { High restoration costs } \\
\text { Indirect economic impacts }\end{array}$ & [11-15] \\
\hline $\begin{array}{l}\text { Kobe (Japan), 1995, M }=7.9 \\
\text { One of the most devastating and destructive earthquakes that hit } \\
\text { Kobe-Osaka in Japan, resulted in blockage of many roads, due to the } \\
\text { damage of more than } 1300 \text { spans of Hanshin expressway, with direct } \\
\text { losses of } \$ 4.6 \text { billion. }\end{array}$ & $\begin{array}{l}\text { Traffic disruption } \\
\text { Obstruction of aid activities } \\
\text { Infrastructure damages } \\
\text { Economic costs } \\
\text { High restoration costs }\end{array}$ & [16-20] \\
\hline $\begin{array}{l}\text { Kocaeli (Turkey), 1999, M = 7.4 } \\
\text { The transportation system in Kocaeli was affected; most of the } \\
\text { damages were related to fault ruptures and ground settlements. The } \\
\text { E80 segment, which is also known as the Trans European Motorway } \\
\text { (TEM) was severely damaged. Roads experienced damages, mainly } \\
\text { in the form of surface ruptures and roadway fills settlement. }\end{array}$ & $\begin{array}{l}\text { Traffic disruption } \\
\text { Possible safety concern } \\
\text { Economic costs } \\
\text { Damage for industrial plants }\end{array}$ & [21-23] \\
\hline $\begin{array}{c}\text { Chi-Chi (Taiwan), } 1999, \mathrm{M}=7.6 \\
\text { One of the largest earthquakes in Taiwan, resulting in extensive } \\
\text { damage to the transport system and infrastructure, particularly in } \\
\text { Taichung and Nantou areas. }\end{array}$ & $\begin{array}{l}\text { Traffic disruption } \\
\text { Safety concern } \\
\text { Direct and indirect economic losses } \\
\text { Economic Repercussions }\end{array}$ & [24-26] \\
\hline $\begin{array}{l}\text { Sichuan (China), 2008, M }=7.9 \\
\text { Several landslides were triggered, which caused a reduction in } \\
\text { accessibility of road network. Rugged mountainous roads were } \\
\text { mainly damaged. The damaged roads obstructed the movement of } \\
\text { heavy machines and emergency vehicles, which led to life losses. }\end{array}$ & $\begin{array}{l}\text { Reduction of accessibility } \\
\text { Obstruction of aid activities } \\
\text { Infrastructure damage } \\
\text { High repair costs } \\
\text { Economic costs }\end{array}$ & {$[27,28]$} \\
\hline $\begin{array}{c}\text { Chile (Chile), 2010, } \mathrm{M}=8.8 \\
\text { One of the most devastating earthquakes in the last decade that } \\
\text { damaged roads and highways in a large area in Chile. Most of the } \\
\text { damages were related to deficiencies in bridges, embankments, and } \\
\text { ground settlements. }\end{array}$ & $\begin{array}{l}\text { Paralyzed road networks } \\
\text { High safety concern } \\
\text { Infrastructure damages } \\
\text { Economic repercussions } \\
\text { Loss of some major lifelines }\end{array}$ & [29-32] \\
\hline $\begin{array}{c}\text { Ranau (Malaysia), } 2015, \mathrm{M}=6.0 \\
\text { One of the highest magnitude earthquakes that was recorded in } \\
\text { Sabah state in the east of Malaysia. Twenty-two roads were damaged } \\
\text { and caused malfunction to road network systems, which obstructed } \\
\text { the movement of emergency vehicle and prevented industrial and } \\
\text { domestic activities for a long time. }\end{array}$ & $\begin{array}{l}\text { Traffic disruption } \\
\text { Obstruction of aid activities } \\
\text { Economic costs } \\
\text { Travel disruption }\end{array}$ & [33-35] \\
\hline
\end{tabular}

M: moment magnitude of earthquake.

The aim of this paper is to shed light on the most common and practical methodologies used to assess the seismic vulnerability of road networks and their assets and to identify the main gaps and needs in this field. In this respect, this paper reviews and discusses available methods, aiming at underpinning the understanding of road network risks and the efficient mitigation measures by transport infrastructure owners and operators. Most of the studies tackling vulnerability assessment of road networks focus on a single criterion, whether it is asset damage, functionality, or network performance. The first section of this paper describes the main types of roadway asset damage, including damage measurement criteria. The second section highlights the main typologies of roadway assets and defines the critical vulnerability factors. The next part reviews available fragility functions and damage states for seismic vulnerability assessment of roadway assets, including a discussion of the fragility assessment methodologies. This is followed by a part that discusses and compares methods that are based on vulnerability indices, including the type of parameters used and their weighting scores. Afterwards, a comprehensive review on assessment of road 
network vulnerability is presented, including two main approaches, the accessibility and link importance method. The final part addresses the integrated seismic risk assessment for a road system, with a focus on the integration between asset damage, functionality, and network traffic. The paper sums up with the knowledge gaps on this topic and provides recommendations for future research, emphasizing the cardinal need to include more technologies for vulnerability assessment, and thus paving the way towards more resilient infrastructure.

\section{Roadway Assets Damage and Their States}

\subsection{Roadway Assets Damage}

A roadway system consists of various assets interacting with the surrounding environmental conditions. Most of the vulnerability assessment methods consider single assets exposed to single hazards and/or surrounding topographical and geomorphological conditions, while recently, Argyroudis et al. [38] introduced the system of assets (SoA) concept for transport infrastructures in diverse ecosystems exposed to multiple hazards.

Furthermore, transport infrastructures can be exposed to accumulation of damage, e.g., after a sequence of seismic events within the lifetime of an asset or an abrupt disruption following a strong event permitting that accumulation [39]. The effect of earthquakes on roadway assets can be classified into different types. Damage is related to ground shaking, commonly represented by peak ground acceleration (PGA), or to ground failure, e.g., due to soil liquefaction, commonly expressed by permanent ground deformation (PGD), as shown in Figure 1a-c. Damage can be direct, affecting directly the roadway and its assets, or indirect, where the cause is eccentric through interaction with other components. Additionally, damage can be structural (physical damage of the roadway), or geotechnical, where the subsurface underneath the roadway and its assets is affected [40], as shown in Figure 1d,e. The damage of roadway assets is described and illustrated in Table 2 and Figure 1. In Figure 1, the black arrows are used to label the type of roadway assets and their structural elements, and the red arrows label the seismic damage for these assets and their elements.

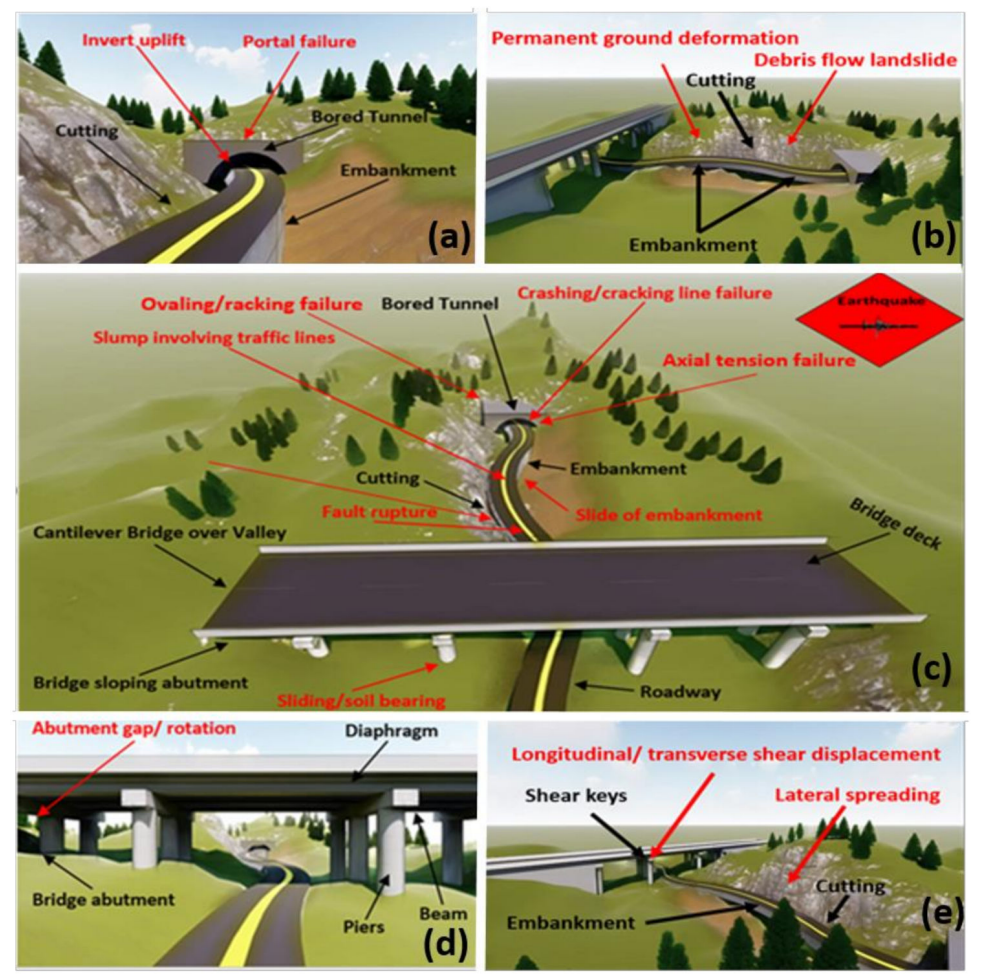

Figure 1. Main types of seismic damage for roadway assets: (a) bored tunnels, (b) cuttings and embankments, (c) overview for various assets, and (d,e) different structural elements of bridges. 
Table 2. Seismic damage of roadway assets.

\begin{tabular}{|c|c|c|c|}
\hline Assets & Type of Damage & Definition & Reference \\
\hline \multirow{2}{*}{$\begin{array}{c}\text { Road } \\
\text { Pavements }\end{array}$} & Direct damage & $\begin{array}{l}\text { Fault ruptures and ground failures due to soil liquefaction and/or } \\
\text { lateral spreading. }\end{array}$ & \multirow{2}{*}{ [41] } \\
\hline & Indirect damage & $\begin{array}{l}\text { Closure of roads due to building collapse and/or collapse of } \\
\text { electricity pylons and failures of underlying pipes. }\end{array}$ & \\
\hline $\begin{array}{l}\text { Slopes and } \\
\text { Trenches }\end{array}$ & $\begin{array}{l}\text { Ground shaking and/or } \\
\text { failure; } \\
\text { geotechnical; and direct } \\
\text { damage }\end{array}$ & $\begin{array}{l}\text { Accumulation of debris on road surface due to earthquake induced } \\
\text { landslides. Structural damages due to landslides that may affect the } \\
\text { pavement, tranches, and slopes near the road. Geotechnical failure } \\
\text { such as permanent ground deformation, lateral spreading, and } \\
\text { shear deformations can affect slopes and trenches. }\end{array}$ & {$[42,43]$} \\
\hline Embankments & $\begin{array}{l}\text { Ground shaking and/or } \\
\text { failure; } \\
\text { structural; and geotechnical } \\
\text { damage }\end{array}$ & $\begin{array}{c}\text { As above. Vulnerability factors depend on the method of } \\
\text { construction, topographical condition, and geometry of } \\
\text { embankments, Figure 1c. }\end{array}$ & {$[44,45]$} \\
\hline Bridges & $\begin{array}{l}\text { Structural damage; indirect } \\
\text { damage }\end{array}$ & $\begin{array}{l}\text { Damage is related to the seismic performance of bridge } \\
\text { components (deck, bearings, piers, shear keys, abutments, } \\
\text { foundations, approach fills). The level and type of failures depend } \\
\text { on the bridge type, the severity of the earthquake, and the local soil } \\
\text { conditions Figure 1d,e. }\end{array}$ & {$[38,46]$} \\
\hline Tunnels & $\begin{array}{l}\text { Ground shaking and/or } \\
\text { failure; structural damage }\end{array}$ & $\begin{array}{l}\text { Damage due to ground failure and ground shaking, including } \\
\text { lining failure, ovaling/racking failure, axial tension failure, axial } \\
\text { compression failure, invert failure, portal failure, Figure 1a. }\end{array}$ & {$[38,47]$} \\
\hline $\begin{array}{l}\text { Retaining } \\
\text { Walls }\end{array}$ & $\begin{array}{l}\text { Ground shaking and/or } \\
\text { failure; geotechnical damage }\end{array}$ & The main type of seismic failure is the backfill settlement (heaving). & [38] \\
\hline
\end{tabular}

\subsection{Damage States for Roadway Assets}

Damage states (DS) are mainly used to evaluate the post-earthquake condition of structures by giving a clear description of failure mechanisms. Furthermore, DS can be used for categorizing the damage of structures in the context of a seismic risk assessment [48]. The damage evaluation criteria are defined by damage thresholds and limits, which define the main boundaries among various damage conditions and states. Different damage criteria were proposed depending on the approach used to formulate fragility models and the type of the asset [49]. Maruyama et al. [50] categorized DS for roadway assets into four main categories (major, moderate, minor, and very minor) as shown in Table 3. The DS were defined based on damage reports after earthquake events in Japan. Argyroudis and Kaynia [51] defined DS for highways and railways in terms of PGD, including into three main grades (minor, moderate, and extensive/complete), which are depicted in Table 4. Furthermore, Argyroudis et al. [52] in Risk-UE approach classified damage for roadways into four main classes (extensive, moderate, minor, and none), including direct and indirect damage with representation of the serviceability of roads after being damaged (Table 5). Nevertheless, Argyroudis and Pitilakis [53] defined DS for tunnels, based on the ratio of the total bending moment $(M)$ due to static and dynamic loading to the capacity bending moment $\left(M_{R d}\right)$ of the lining section. $M_{R d}$ corresponds to the first yielding of the steel, assuming that the lining behaves as a beam section (Table 6). Finally, DS for bridges are commonly defined based on the performance of the most vulnerable bridge components, since a bridge is considered as a serial system in various studies. For example, Nielson and DesRoches [54] and Padgett and DesRoches [55] defined DS for typical and multi-span bridges, respectively, by developing a fragility curve through integrating all potential failure aspects of the combined seismic probabilistic demand models by producing an integration between random bridge models of different parameters and specific geometric bridge models. This integration helps in reducing the margin of the probability distribution through developing a single joint for the probability distributions. 
Table 3. Damage states of roadway assets in Japan [50].

\begin{tabular}{ccccc}
\hline Damage & Major & Moderate & Minor & Very Minor \\
\hline Side Slope & Total Collapse & Partial Collapse & Deformation & - \\
\hline Gap in Roadway & & & Traffic lane: & \\
(horizontal & - & Traffic lane: $>3 \mathrm{~cm}$ & $1-3 \mathrm{~cm}$ & Traffic lane: \\
displacement) & & Shoulder: $>20 \mathrm{~cm}$ & $\begin{array}{c}\text { Shoulder: } \\
1-20 \mathrm{~cm}\end{array}$ & $<1 \mathrm{~cm}$ \\
\hline Crack in Roadway & - & & $3-5 \mathrm{~cm}$ & $<3 \mathrm{~cm}$ \\
\hline
\end{tabular}

Table 4. Highway damage states [51].

\begin{tabular}{ccccc}
\hline Damage State & \multicolumn{2}{c}{$\begin{array}{c}\text { Permanent Vertical Ground } \\
\text { Displacement (m) }\end{array}$} & Serviceability \\
\hline Min & Max & Mean & \\
\hline Minor & 0.02 & 0.08 & 0.05 & $\begin{array}{c}\text { Open, reduced speeds or partially } \\
\text { closed during repair }\end{array}$ \\
\hline Moderate & 0.08 & 0.22 & 0.15 & $\begin{array}{c}\text { Closed or partially closed during } \\
\text { repair works }\end{array}$ \\
\hline Extensive/Complete & 0.22 & 0.58 & 0.40 & Closed during repair works \\
\hline
\end{tabular}

Table 5. Damage states of roads [52].

\begin{tabular}{cccc}
\hline Serviceability & Damage States & Direct Damages & Indirect Damages \\
\hline $\begin{array}{c}\text { Fully closed due to } \\
\text { temporary repairs for few } \\
\text { days to few weeks. } \\
\begin{array}{c}\text { Partially closed to traffic due } \\
\text { to permanent repairs for few } \\
\text { weeks to few months. }\end{array}\end{array}$ & Extensive & $\begin{array}{c}\text { Major settlement or } \\
\text { offset of the ground } \\
(>60 \mathrm{~cm})\end{array}$ & $\begin{array}{c}\text { Considerable debris } \\
\text { of collapsed } \\
\text { structures }\end{array}$ \\
\hline $\begin{array}{c}\text { Fully closed due to } \\
\text { temporary repairs for few } \\
\text { days. Partially closed to } \\
\text { traffic due to permanent } \\
\text { repairs for few weeks. }\end{array}$ & Moderate & $\begin{array}{c}\text { Moderate } \\
\text { of the ground } \\
(30 \text { to } 60 \mathrm{~cm})\end{array}$ & $\begin{array}{c}\text { Moderate amount } \\
\text { of debris of } \\
\text { collapsed structures }\end{array}$ \\
\hline $\begin{array}{c}\text { Open to traffic. Reduced } \\
\text { speed during repairs. }\end{array}$ & Minor & $\begin{array}{c}\text { Slight settlement } \\
(<30 \mathrm{~cm}) \text { or offset of } \\
\text { the ground }\end{array}$ & $\begin{array}{c}\text { Minor amount of } \\
\text { debris of collapsed } \\
\text { structures }\end{array}$ \\
\hline Fully open. & None & - & $\begin{array}{c}\text { No damage/Clean } \\
\text { road }\end{array}$ \\
\hline
\end{tabular}

Table 6. Tunnel lining damage states [53].

\begin{tabular}{ccc}
\hline Damage State & Damage Index & Central Value of Damage Index \\
\hline Ds0. None & $M / M_{R d} \leq 1.0$ & - \\
\hline Ds1. Minor/slight & $1.0<M / M_{R d} \leq 1.5$ & 1.25 \\
\hline Ds2. Moderate & $1.5<M / M_{R d} \leq 2.5$ & 2.00 \\
\hline Ds3. Extensive & $2.5<M / M_{R d} \leq 3.5$ & 3.00 \\
\hline Ds4. Collapse & $M / M_{R d}>3.5$ & - \\
\hline
\end{tabular}

$M$ : Actual bending moment. $M_{R d}$ : Capacity-bending moment. 


\section{Main Typologies for Vulnerability Assessment of Roadway Assets}

This section includes the main vulnerability factors of roadway assets, i.e., the classification of soil and the functional hierarchical road categorization. The typologies of road pavements and geotechnical assets (embankments, cuts, trenches) are also described. Other structural assets, e.g., bridges, tunnels, and retaining walls are not included here and are described elsewhere $[38,56,57]$.

\subsection{Classification of Soil}

Roadway assets are geotechnical structures, so the soil is considered a main factor for their vulnerability assessment. Various soil classifications are available to specify the type of the soil according to different variables and parameters. One of the most widely used classifications is the one given by Eurocode 8 [58], which categorized the type of soil into four categories: soil A (rock), B (very dense sand), C (medium dense sand), D (loose-tomedium cohesion-less soil), and $\mathrm{E}$ (soil profile consisting of a surface alluvium layer).

\subsection{Functional Hierarchical Road Categorization}

The classification of roads according to their functional hierarchy includes six types, which are local streets, minor collectors, major collectors, minor arterials, major arterials, and freeways [59,60]. Different factors are used in this classification, such as accessibility, mobility, geometry, speed limits, and number of lanes [61]. For instance, Goto and Nakamura [62] categorized roads' hierarchy using the characteristics of the surrounding area, i.e., access control, place status, road surface, link role, and transport mode. Other studies considered a relation between local roads and high speed $[63,64]$.

\subsection{Road Pavements}

The major parameter of typology is the number of lanes. Adafer and Bensaibi [65] used pavement type as an additional parameter for assessing a vulnerability index (VI) of roads. Moreover, Benedetto and Chiavari [66] used the pavement condition as a vulnerability parameter for floods, while a specific weight was assigned for each parameter.

\subsection{Embankments, Slopes, and Trenches}

The main parameters are the geometrical characteristics such as the height of embankments and slope angles [38]. Some researchers used compaction quality of the embankments as an additional vulnerability factor $[65,67]$.

\subsection{Tunnels}

The main factors that influence tunnels are the shape and dimensions of the structure, the main properties of the surrounding soil and/or rock (geological conditions), and the supporting system (e.g., steel, concrete, or masonry) [47].

\subsection{Bridges and Retaining Walls}

The damage of bridges is mainly related to the seismic performance of bridge components (i.e., deck, bearings, piers, shear keys, abutments, foundations, approach fills), which might be affected differently depending on the bridge type, the severity of the earthquake, and the local soil conditions. Moreover, the important typological characteristics for bridge abutments and retaining walls include the type of the abutment and its foundation, the soil conditions of foundation, and the fill material (backfill behind retaining walls/abutments) $[38,68]$.

\section{Fragility Functions for Vulnerability Assessment of Roadway Assets}

Fragility functions is a key element in seismic risk assessment; it is described by relating a given level of seismic intensity with the probability of reaching or exceeding a given level of damage. The structural damage is quantified based on engineering demand parameters (EDP) such as vertical displacements, crack patterns, or rotations in order to 
estimate the performance limit states based on performance based seismic design (PBSD) during ground motion excitations $[69,70]$. Different methods can be used to conduct fragility curves such as empirical, analytical, judgemental, and hybrid [47].

\subsection{Empirical Method}

It relies on post-earthquake survey and damage statistics for developing empirical fragility curves. The reliability of the results depends mainly on the completeness and variety of the empirical data collected from past earthquakes. Moreover, the empirical fragility curves can have a large variation due to differences in the observed damage datasets, such as the number of samples observed, the road assets typology, soil types, and range of ground motions [71]. Different researchers have developed and validated different empirical fragility curves for roadway assets. Kaynia et al. [47] validated the results of the empirical fragility curves tailored for road pavements, which are presented in HAZUS [72] using a combination of expert judgmental models and empirical models that were conducted by Giovinazzi and King [73]. Furthermore, Maruyama et al. [50] and Oblak et al. [74] conducted and assessed, respectively, the empirical fragility curves of embankments. In addition to that, new methods are being used to develop empirical fragility models by considering nonspecific damage data. For instance, Kim [75] formulated a framework based on the possibility theory, which considers the fragility functions nested to each other. The resulted possibility-based fragility function demonstrated by two main measures, certainty and possibility, are compared with the traditional fragility curves that are based on probability.

\subsection{Analytical Method}

Analytical fragility curves mainly analyze the damage distribution on any structure of increasing earthquake loadings based on structural models. The damage levels are defined based on a specific damage state classification [76]. In addition to that, the selection of ground motion records is a fundamental tool to obtain an incremental dynamic analysis to develop the fragility curves, as proposed by several seismic codes that recommend a minimum of three or seven sets of ground motions. The ground motions can be chosen based on several parameters such as magnitude $(\mathrm{Mw})$, soil type, or epicentral distance. This method has high efficiency compared to other methods, although the limitation of the method has not been fully investigated [77]. Argyroudis and Kaynia [40] studied the fragility functions of roadway assets by analyzing the level of damage in road assets through a specific damage index (DI) representing the EDP, which is affected by increasing intensity of earthquake excitation. Figure 2 illustrates a graph in Ln scale, where the horizontal axis corresponds to the hazard intensity, expressed by a specific measure, e.g., PGA (g), and the vertical axis shows the adopted damage index. The latter is expressed based on a specific response parameter of the numerical model, e.g., the vertical displacement of a road embankment or the drift of a bridge pier. The different points of the graph represent the results of the numerical analyses (i.e., estimated DI) for different hazard intensities. The solid line is produced based on regression analysis and describes the correlation between the DI and the intensity measure (IM). This regression curve is used to define the median of the intensity that is responsible for the $i_{\text {th }}$ damage, based on the corresponding mean or central value of the $\mathrm{DI}_{(\mathrm{dsi})}$ (e.g., Tables 3, 4 and 6). The standard deviation of the residuals, i.e., vertical distance between the data point and the regression line, defines the variability of the seismic demand [40]. It is commonly referred as $\beta_{\mathrm{D}}$ (see also Table 5) and describes the uncertainty in response due to variation in ground motion properties [78]. Panchireddi and Ghosh [79] applied an approach based on the Park and Ang damage index [80] to investigate the vulnerability of bridges against earthquakes. Similar methods focused on vulnerability assessment of bridges by using the Park and Ang Damage Index (DI) [81-83]. Baker [84] investigated the efficiency of fragility functions by applying dynamic structural analysis. The study focused on evaluating the approaches, which are used to develop the fragility functions. The fitting approach focuses on statistical inference concepts, which 
works on a specific number of IM levels by analyzing multiple strips. The results showed that the fitting approach for fragility functions used in this research is appropriate and easy to implement. Furthermore, Argyroudis et al. [38] performed a study to investigate the fragility of transportation infrastructure systems, by representing all the existing information and synthesizing it. Moreover, Lu et al. [85] formulated a model to assess the fragility of pavement infrastructure due to different environmental conditions. The research formulated a pavement fragility method that relies on lognormal cumulative distribution functions.

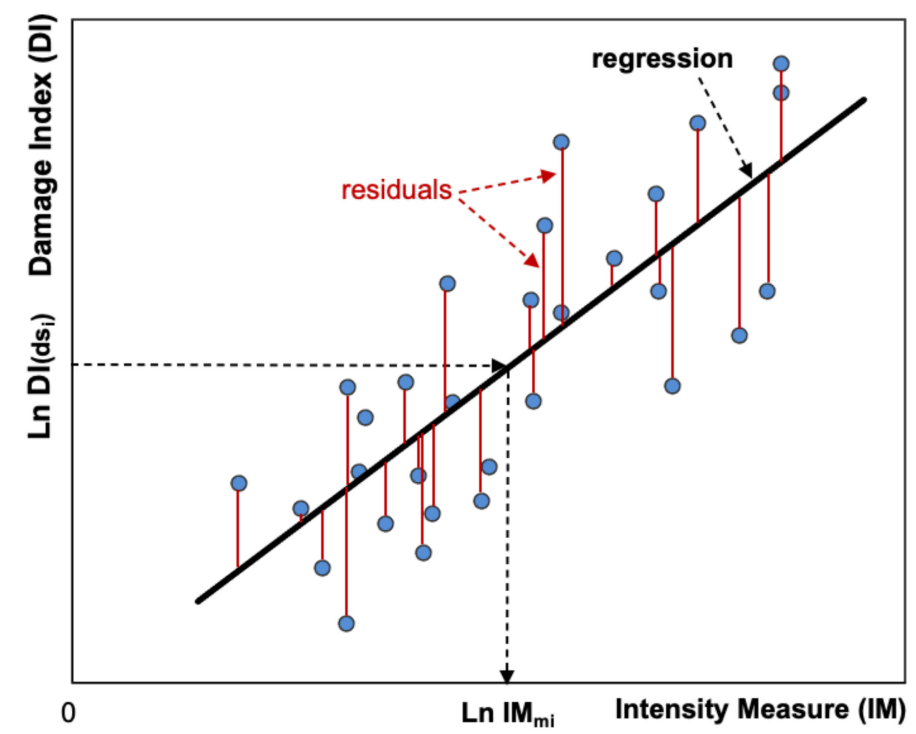

Figure 2. Example of damage evolution with respect to earthquake IM and regression analysis.

\subsection{Expert-Based Judgement Method}

Several judgmental fragility functions were built based on professional experience and experts' opinion through questionnaires. This method is simple and fast in derivation, but the reliability of the results is uncertain, since this methodology is not focused on experimental evidence but is based solely on professional judgement [86]. For instance, Winter et al. [87] determined the physical vulnerability for roads exposed to landslides based on questionnaires filled by experts regarding the probability of road closure for different volumes of debris. Moreover, HAZUS methodology includes fragility models based on a combination of expert observations and empirical data from previous earthquakes [88]. Werner et al. [89] formulated a method that relies on REDARS 2 modules, by which an expert judgmental approach can be conducted to evaluate the main parameters of formulated PGD threshold values for abutment and road pavements. Moreover, ATC-13 [90] defined six slope classes by formulating an expert judgment model that depends on matrices for slope failure probability. These approaches provide useful assessments when insufficient empirical data are available, or when the numerical modelling is very demanding.

\subsection{Hybrid Method}

The hybrid method uses different approaches to combine analytical, observational, and judgmental data. This approach can be beneficial to calibrate analytical results with experimental or empirical data. In this respect, the computational effort might be reduced, while the reliability of the fragility model is increased. Additionally, the hybrid method can be more efficient than other methods, because it is merging different sources of data, which can overcome the limitations and reduce the error of other methods [91,92]. Moreover, it takes into consideration all types of uncertainties, which is not available in the empirical and analytical approach. 


\subsection{Equations for Generating Fragility Functions}

The fragility functions depend on uncertain values, which are known as random variables, i.e., damage measures (DM) and intensity measures (IM). The uncertainty in fragility functions is due to unpredictable change in the seismic intensity measures generated from different ground motions due to the uncertain behavior of roadways under seismic loading. For instance, the capacity of road infrastructure will not change with time, but the capacity of this infrastructure is uncertain during and post-earthquake [93]. The fragility functions are commonly described by a lognormal probability distribution as shown in Equation (1).

$$
P_{f}\left(d s \geq d s_{i}\right)=\phi\left[\frac{1}{\beta_{t o t}} \times \ln \left(\frac{S}{S_{m i}}\right)\right]
$$

where, $\left(P_{f}\right)$ is the probability of reaching or exceeding a particular damage state $\left(d s_{i}\right),(\phi)$ is the standard cumulative probability function, $\left(S_{m i}\right)$ is the median threshold value of the earthquake parameter $S$ (e.g., peak ground acceleration-PGA) required to cause the $i_{t h}$ damage state, and $\left(\beta_{t o t}\right)$ is the total lognormal standard deviation. Various equations were employed for expressing fragility curves of roadway assets. An overview of representative equations for different assets (e.g., embankments, road pavements, bridges, trenches and slopes, and tunnels) is presented in Table 7.

Table 7. Equations describing fragility functions.

\begin{tabular}{|c|c|c|c|}
\hline Asset & Equation & Parameters & Reference \\
\hline $\begin{array}{l}\text { Typical } \\
\text { bridges }\end{array}$ & $P[D>C \mid I M]=\phi\left[\frac{\ln \left(S_{d} / S_{c}\right)}{\sqrt{\beta_{d \mid I M}^{2}+\beta_{c}^{2}}}\right]$ & $\begin{array}{c}S_{d}: \text { median estimate of the demand as a function } \\
\text { of } I M, S_{c}: \text { median estimate of the capacity. } \\
\beta_{d \mid I M}: \operatorname{logarithmic} \text { standard deviation of the } \\
\text { demand conditioned on the intensity measure. } \\
\beta_{c}: \text { dispersion of the capacity, } \phi: \text { standard } \\
\text { normal cumulative distribution function. }\end{array}$ & {$[54,55]$} \\
\hline Embankments & $P=C \phi\left(\left(\frac{\ln P G V-\lambda}{\zeta}\right)\right)$ & $\begin{array}{c}\phi(x): \text { standard normal distribution function. } \\
\lambda, \zeta, \text { and } C: \text { constants calculated by regression } \\
\text { analysis. }\end{array}$ & [94] \\
\hline $\begin{array}{l}\text { Embankments } \\
\text { Trenches/ } \\
\text { slopes }\end{array}$ & $P\left(D>D S_{k}\right)=\frac{1}{2}\left[1+\operatorname{erf}\left(\frac{\ln P G A-\ln \mu}{\beta \sqrt{2}}\right)\right]$ & $\begin{array}{c}\text { erf: error function. } \\
\mu: \text { median of fragility curve, } \beta \text { : lognormal } \\
\text { standard deviation. }\end{array}$ & [47] \\
\hline Bridges & $P[D \geq C \mid I M]=\phi\left(\frac{\ln \left(S_{D} / S_{C}\right)}{\sqrt{\beta_{t o t}^{2}}}\right)$ & $\begin{array}{l}S_{D} \text { and } S_{C} \text { : median values for demand } C \text { and } D . \\
\qquad \beta_{t o t} \text { : total uncertainty. } \\
\beta_{t o t}=\beta_{D S}^{2}+\beta_{D}^{2}+\beta_{C}^{2} \\
\text { where, } \beta_{D s} \text { is the variability of damage state, } \beta_{D} \\
\text { is the variability of seismic demand, and } \beta_{C} \text { is } \\
\text { the variability of capacity. }\end{array}$ & [95] \\
\hline $\begin{array}{l}\text { Embankments } \\
\text { Tunnels }\end{array}$ & $P_{f}\left(d s>d s_{i} \mid S\right)=\phi\left[\frac{1}{\beta_{t o t}} \times \ln \left(\frac{I M}{I M_{m i}}\right)\right]$ & $\begin{array}{l}\phi: \text { standard cumulative probability function. } \\
I M_{m i}: \text { median threshold of intensity measure. } \\
\beta_{\text {tot }}: \text { total lognormal standard deviation. }\end{array}$ & {$[51,96]$} \\
\hline $\begin{array}{c}\text { Road } \\
\text { pavements }\end{array}$ & $P_{\text {Fragility }}=P($ Damage $\mid E P=x)=\phi\left(\frac{\ln x-\alpha}{\beta}\right)$ & $\begin{array}{l}\phi: \text { distribution function of standard normal } \\
\text { distribution } \alpha \text { and } \beta \text { : logarithmic mean and } \\
\text { logarithmic standard deviation of EP. }\end{array}$ & [83] \\
\hline Tunnels & $F_{R}(D s \geq D s i \mid \mathrm{IM})=\phi\left(\frac{I M}{\sqrt{\beta_{D s}^{2}+\beta_{D}^{2}+\beta_{C}^{2}}}\right)$ & $\begin{array}{c}\phi: \text { cumulative probabilistic function of fragility } \\
\text { functions. } \\
\beta_{D s}: \text { variability of damage state, } \beta_{D} \text { : variability } \\
\text { of seismic demand, } \beta_{C} \text { : variability of tunnel } \\
\text { capacity }\end{array}$ & [97] \\
\hline
\end{tabular}

Figure 3 illustrates some samples representing the fragility functions of roads and tunnel linings, by which the damage states of roads are categorized into three and four main categories, correspondingly. Assessing the vulnerability of roadway assets using 
fragility curves is a vital method for performing quantitative risk analysis in component or network level [98]. Yet, the assessment of vulnerability for roadway assets can be conducted by using the VI method, which is described in the following section.
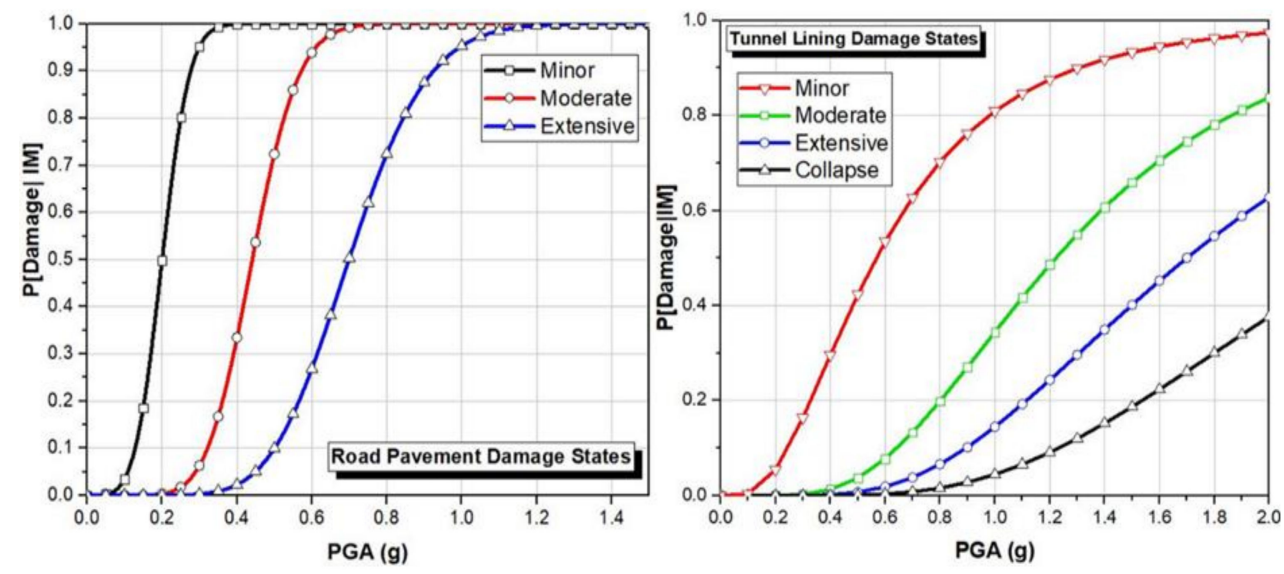

Figure 3. Samples of fragility functions for road pavement and tunnel lining.

\section{Vulnerability Index for Roadway Infrastructures Based on Physical Approach}

Vulnerability index (VI) approaches assess roadway infrastructure based on different parameters, which describe the vulnerability of the infrastructure to seismic events $[99,100]$. VI methods have been developed individually for bridges and other assets; however, the focus of this review is on assets other than bridges.

\subsection{Vulnerability Parameters}

VI is mainly related to the intrinsic characteristic of roadway infrastructures, but it is independent to any external factors. The number of parameters used varies depending upon the type of vulnerability understudy and the main context of this VI.

Francini et al. [100] used four different parameters to formulate a VI for urban roads: (i) the length of the road, (ii) the width of the road, (iii) redundancy level of the road, and (iv) critical elements (bridges, intersections, underpasses, tunnels, and other elements that could affect the vulnerability of the system). The VI of each road segment is calculated according to Equation (2):

$$
I_{v_{j}}=\sum_{i=1}^{n} w_{i} P_{a_{i}}
$$

where, $I_{v_{j}}$ is the Vulnerability Index of the $j$-th alternative road, $w_{i}$ is the weight relative to the $i$-th parameter, $P_{a_{i}}$ is the is the $i$-th parameter, and $n=1$ to 4 .

Moreover, Adafer and Bensaibi [65] proposed an index-based method, based on various literature reviews from previous earthquakes worldwide, including ground motion characterization, fragility curves, and traffic analysis during earthquake. This VI is developed based on different factors shown in Table 8 that are weighted according to the analytical hierarchy process (AHP) method.

Table 8. Vulnerability index factors [65].

\begin{tabular}{ccc}
\hline Parameter & Item & Factor \\
\hline \multirow{3}{*}{ Structural } & Pavement & $\begin{array}{c}\text { Number of lane } \\
\text { Pavement type }\end{array}$ \\
\cline { 2 - 3 } & Ground conditions & Ground type \\
\cline { 2 - 3 } & Embankment & Height \\
\cline { 2 - 3 } & Maintenance condition & Pavement conditions \\
\hline Hazard & Seismic intensity & - \\
\hline
\end{tabular}


The VI is formulated to study the effect of those factors on the response of roads against seismic action based on Equation (3).

$$
V I=\sum_{i=1}^{2} W_{i} \sum_{j=1}^{3 o r 4} W_{i j} \sum_{k=1}^{2 o r 3} W_{i j k} \cdot C_{i j k l}
$$

where, $W_{i}$ is the weighting coefficient of structural or hazard parameter, $W_{i j}$ is the weighting coefficient of the item, $W_{i j k}$ is the weighting coefficient of factor, and $C_{i j k l}$ is the score of the factors, where $1=2,3,4$, or 5 .

In addition, various VI based methods were developed to study vulnerability of bridges [101-103]. Federal Highway Administration (FHWA) described the indices method for rating the vulnerability of bridges. The VI is used in this method to rate and prioritize the vulnerability of bridges, where various components of the bridge are assessed (connections, bearings, columns, piers, foundations, abutments, and soils) and rated according to different rate values. The vulnerability ratings for connections, bearings, and seat widths are calculated together to form vulnerability set V1, while column vulnerability rating (CVR), abutment vulnerability rating (AVR), and liquefaction vulnerability rating (LVR) are added together in the other vulnerability set, V2. The highest set is considered as the overall VI value for ranking the bridge [56].

\subsection{Weighting of Vulnerability Parameters}

Weighting factors are commonly employed to assess the contribution of the different parameters to the road vulnerability. In this respect, Francini et al. [100] used the AHP method to weight the vulnerability parameters. For assignment of the scores for each weight, a pairwise comparative matrix is applied, as per the three areas indicated in Table 9. In particular, the table is split into three major segments, an upper triangular section of the table colored in dark orange, a lower triangular section of the table colored in light orange, and a line in the center (mean diagonal) separating the two triangular parts. In order to calculate the weight percentage $w_{i}$, an eigenvalue problem should be conducted, as shown in Equation (4) below [104].

$$
w=\frac{v_{\lambda}}{\sum_{i=1}^{n} v_{\lambda}(i)}=\left[\begin{array}{l}
24.20 \% \\
11.07 \% \\
45.00 \% \\
19.10 \%
\end{array}\right]
$$

where $w$ is the weight factor and $v_{\lambda}$ is the relative Eigen vector of the matrix.

A consistency index $(C I)$ is also developed, for achieving matrix consistency, as shown in Equation (5). The CI can be calculated by determining random consistency index (RI) as shown in Equation (6). $R I$ is based on different values for variation of matrix size (Table 10).

$$
C I=\frac{\lambda-n}{n-1}
$$

where $C I$ is the consistency index, $\lambda$ is a maximum Eigen value, and $n$ is the size of the matrix.

$$
C R=\frac{C I}{R I}
$$

where $C R$ is the consistency ratio and $R I$ is the random consistency index. 
Table 9. Pairwise comparative matrix $(n \times n)$ [100].

\begin{tabular}{ccccc}
\hline & Road Length & Road Width & Critical Elements & Redundancy \\
\hline Road Length & 1 & 2 & $1 / 3$ & 2 \\
\hline Road Width & $1 / 2$ & 1 & $1 / 3$ & $1 / 2$ \\
\hline Critical Elements & 3 & 3 & 1 & 2 \\
\hline Redundancy & $1 / 2$ & 2 & $1 / 2$ & 1 \\
\hline
\end{tabular}

Table 10. $R I$ values in term of matrix size $n$ [100].

\begin{tabular}{cccccccccccc}
\hline $\boldsymbol{n}$ & $\mathbf{1}$ & $\mathbf{2}$ & $\mathbf{3}$ & $\mathbf{4}$ & $\mathbf{5}$ & $\mathbf{6}$ & $\mathbf{7}$ & $\mathbf{8}$ & $\mathbf{9}$ & $\mathbf{1 0}$ \\
\hline$R I$ & 0 & 0 & 0.58 & 0.9 & 1.12 & 1.24 & 1.32 & 1.41 & 1.45 & 1.49 \\
\hline
\end{tabular}

$n$ : Size of the matrix. RI: Random consistency index.

After assignment of scores by calculating the matrix, the main weights of each parameter are established, and the VI of the roads is calculated based on Equation (7). The parameter that is related to critical element $P_{C E_{j}}$ is the most influential, with a weighting factor 0.450, while the least important parameter is related to length of roadway $P_{L_{j}}$, with a weighting factor 0.242 .

$$
I_{v_{j}}=0.242 \times P_{L_{j}}+0.177 \times P_{W_{j}}+0.450 \times P_{C E_{j}}+0.191 \times P_{R_{j}}
$$

Similarly, Adafer and Bensaibi [65] conducted the VI method by defining seven main items and nine main factors, which are divided into two main parameters, i.e., structural and hazard. The main items and factors are weighted using the AHP method, as shown in Table 11.

Table 11. Weighted items and factors [65].

\begin{tabular}{|c|c|c|c|c|}
\hline Parameter & Item & Weight $\left(W_{i j}\right)$ & Factor & Weight $\left(W_{i j k}\right)$ \\
\hline \multirow[t]{8}{*}{ Structural } & Pavement & 0.108 & Number of lanes & 0.667 \\
\hline & \multirow{2}{*}{ Ground conditions } & \multirow{2}{*}{0.561} & Pavement type & 0.333 \\
\hline & & & Height & 0.648 \\
\hline & Embankment & 0.283 & Compaction quality & 0.122 \\
\hline & \multirow{4}{*}{$\begin{array}{l}\text { Maintenance } \\
\text { condition }\end{array}$} & \multirow{4}{*}{0.048} & Ground type & 0.200 \\
\hline & & & Landslides potential & 0.800 \\
\hline & & & Pavement conditions & 0.667 \\
\hline & & & $\begin{array}{l}\text { Slope protection } \\
\text { measures }\end{array}$ & 0.333 \\
\hline Parameter & Item & Weight $\left(W_{i j}\right)$ & Factor & Weight $\left(W_{i j k}\right)$ \\
\hline \multirow[t]{3}{*}{ Hazard } & Seismic intensity & 0.633 & - & - \\
\hline & Liquefaction potential & 0.106 & - & - \\
\hline & Intersection with fault & 0.261 & - & - \\
\hline
\end{tabular}

$W_{i j}$ : weighting coefficient of the item. $W_{i j k}$ : weighting coefficient of the factor.

\subsection{Vulnerability Rating}

Adafer and Bensaibi [65] proposed three different categories for the vulnerability of roads based on the range of the estimated VI as shown in Figure 4: VR1 (safe: VI =10-20), VR2 (moderately resistant: VI $=20-35$ ), and VR3 (low resistant: VI $=35-50$ ). 


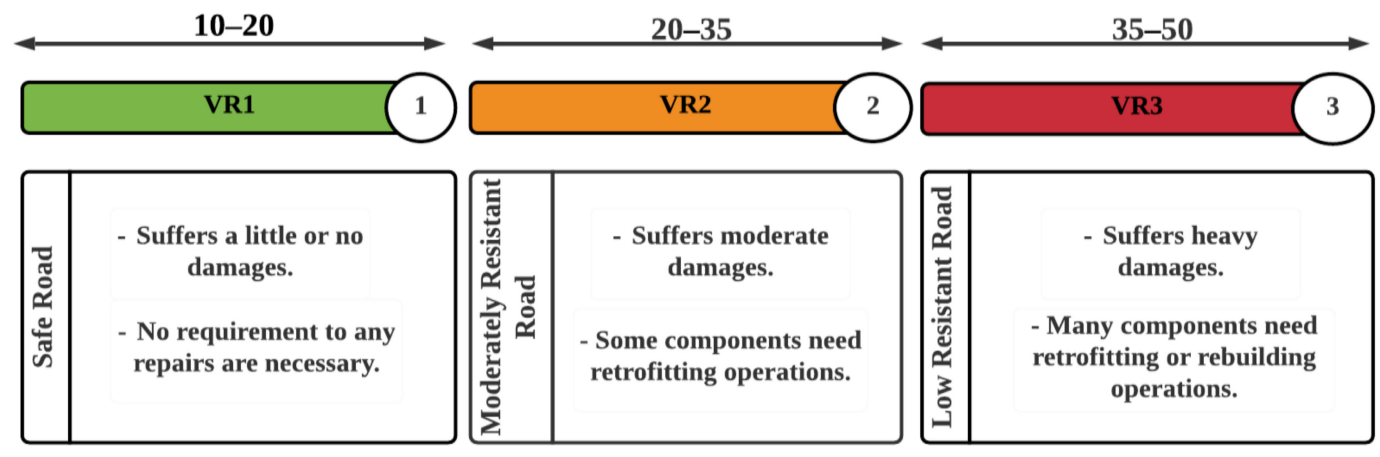

Figure 4. Categories of vulnerability index developed from Adafer and Bensaibi [65].

The vulnerability parameters were classified into two main groups, including structural and hazard criteria. The hazard parameter $\left(W_{i}\right)$ was weighted as 0.75 , which is higher than the structural parameter by 0.25 . However, Francini et al. [100] focused more on the structural elements and the surroundings by categorizing the parameters into qualitative estimates and quantitative measurements of the roads under study.

Mainly the type of parameters used and the weighting score for those parameters can affect critically the values of VI. Adafer and Bensaibi [65] conducted a study in Algeria and obtained VI values that are equal to 0.271 for the roads of Ain Temouchent region and 0.580 for the roads of Zemmouri region. While Francini et al. [100] assessed the vulnerability of two alternative roads for emergency plan in Italy for Rende Municipality. The study resulted in two different values for VI of the two alternative roads, which are 0.096 for the first road and 0.174 for the second road. The classification of the roads with their VI values is shown in Table 12. This variation in VI value, in response to the change of the parameters used and their weighting score coefficient, is controversial. Additional empirical data are required to improve the applicability of VI methods and to reduce the variation between the weighting coefficients of the parameters. Nevertheless, the parameters must be prioritized from the most to the least influential after investigating different VI methods.

Table 12. Prioritization of VI values for roads.

\begin{tabular}{cccc}
\hline Roads Under Study & VI & Classification & Reference \\
\hline Ain Temouchent region roads & 0.271 & Safe & Adafer and Bensaibi [65] \\
Zemmouri region roads & 0.580 & Moderate Damage & \\
\hline Alternative road 1 & 0.096 & Safe & Francini et al. [100] \\
Alternative road 2 & 0.174 & Safe & \\
\hline
\end{tabular}

\subsection{Comparison Between Physical Vulnerability Assessment Methods}

The physical vulnerability assessment of roadway assets focuses on assessing the expected degree of direct physical damage (Table 2), which can be studied by using fragility functions (see Section 4) and vulnerability indexes (see Section 5). The main steps of the two methods are illustrated in Figure 5. They are essential for understanding the risks of the network and for identifying the most vulnerable assets while they support efficient risk reduction strategies and emergency planning by the infrastructure owners. The fragility functions provide the damage probability for a given seismic intensity, which is a key factor in quantitative risk analysis (QRA) and estimation of direct losses [105]. This approach is becoming more and more prevalent today, with fragility functions being generated and applied to various infrastructure assets exposed to diverse hazards around the world. The VI approach results in a rating of the assets' vulnerability based on different parameters and weighting factors. Therefore, it does not provide loss estimations, but is useful for prioritization purposes, in particular as part of periodical assessments of different components of the network. Hence, it is considered as an important tool toward efficient risk management and allocation of resources. 
Potential improvements include the development of new analytical and/or hybridbased models for roadway assets for which limited fragility functions are available, i.e., road pavements and slopes, and considering geotechnical and topographical conditions as well as multi-hazard effects. The derived results should be compared and verified with expert-based approaches and/or empirical data if available. Further improvements regarding the VI methods include the definition of the most critical parameters and the adjustment of weighting score coefficients based on empirical data and sensitivity analyses as well as comparative studies between different VI methods to assess and evaluate the main parameters used in these approaches. Finally, future research may formulate an alternative approach by using vulnerability indices to adjust generic fragility curves, taking into account the characteristics of specific assets such as geometry, age, structural conditions, etc.

\section{Physical Vulnerability Assessment of Roadway Assets}
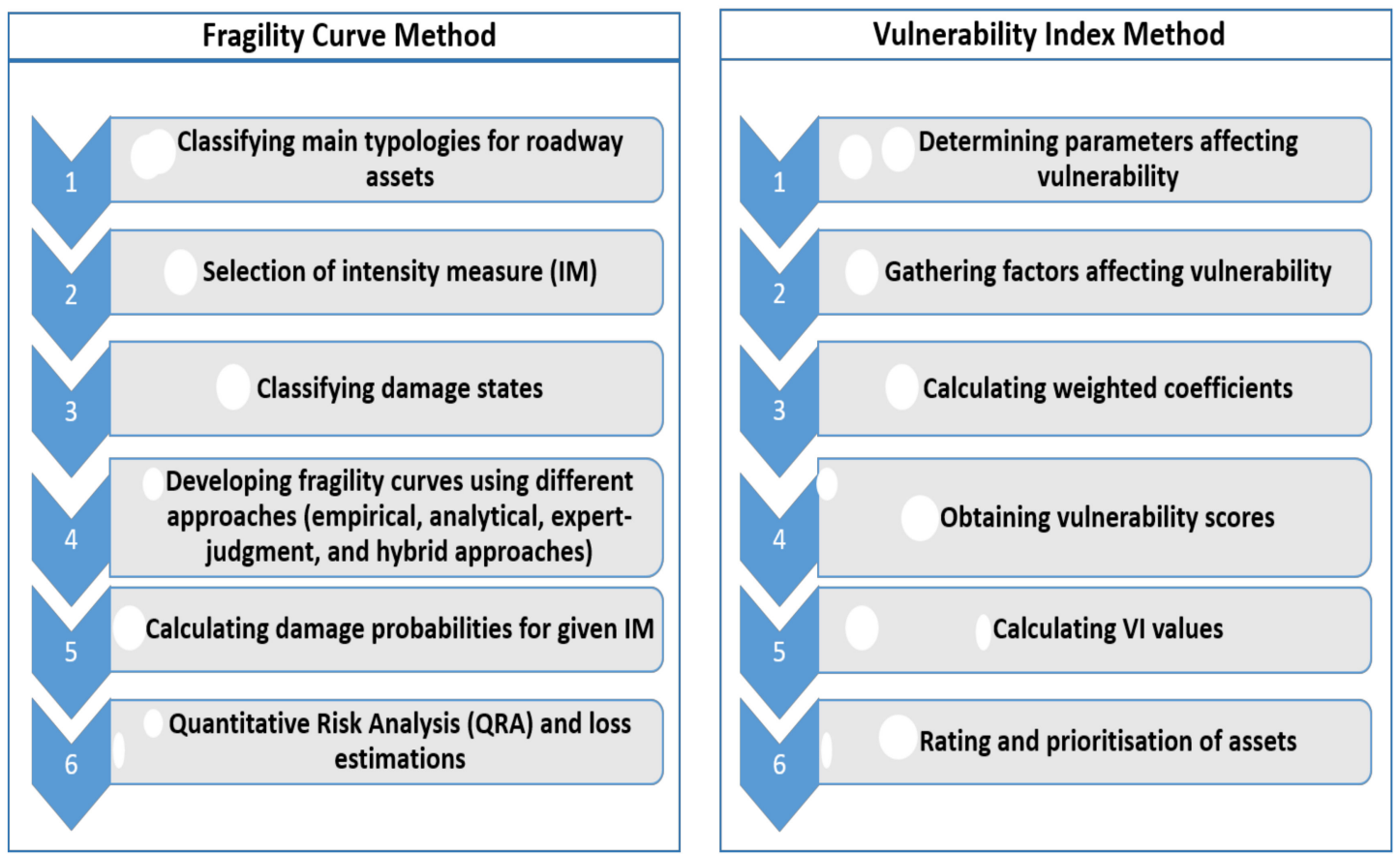

Figure 5. Physical vulnerability assessment methods for roadway assets.

\section{Assessment of Road Network Vulnerability Using Traffic-Based Approach}

Assessing the vulnerability of a road network by evaluating its accessibility provides useful information for the functionality and traffic capacity of roads. The connectivity and operability of the road define the term accessibility. In other words, a road is accessible whenever it is connected (structurally) and operable (functionally). The most critical factor for assessing the traffic capacity and functionality is the direct physical damage of the road elements. The vulnerability assessment does not investigate the road network as a whole, but identifies the most vulnerable points (weak points) in the network [106] (see Sections 4 and 5). To analyze the vulnerability of any road network, it is essential to divide the network into elements, including nodes and links as shown in Figure 6 below. Mainly, nodes represent the point elements, where the user can enter from (e.g., intersections and bridges) or change the direction of travel (e.g., ramps, road interchanges, and roundabouts). Links are linear elements, which connect the nodes [107]. The classification of road network components depends on different factors, such as the length, connection, path, cycle, circuit, or importance of these components inside a specific road network. Kilanitis and Sextos [108] described the road network configuration in groups of nodes (intersections and other points of interest), links (road segments), and key component (bridges). Nevertheless, Merschman 
et al. [109] considered intersections, endpoints, and zones as the main nodes for the road network. In addition, the study of a system of assets (e.g., roadway on embankment and a retaining wall in one of its sides) or grade separation of roads (planarity conditions) requires more advanced network-based analysis [110-113]. Eventually, modelling a road network and classifying its components as nodes or links is considered a complicated process, as it depends on the scope of the analysis and the level of required detail. To assess the network, different vulnerability scores are assigned to its damaged links and nodes, which are prioritized according to their infrastructure condition, as shown in Figure 6. These scores can be based on fragility curves results (damage probabilities) and/or VI calculations (see Sections 4 and 5). Various methods were employed to assess the road network vulnerability and subsequently functionality, based on their accessibility and the importance of transportation links, which stay operative after an earthquake. Two of these methods, the accessibility index and the link importance index, are described in the following.

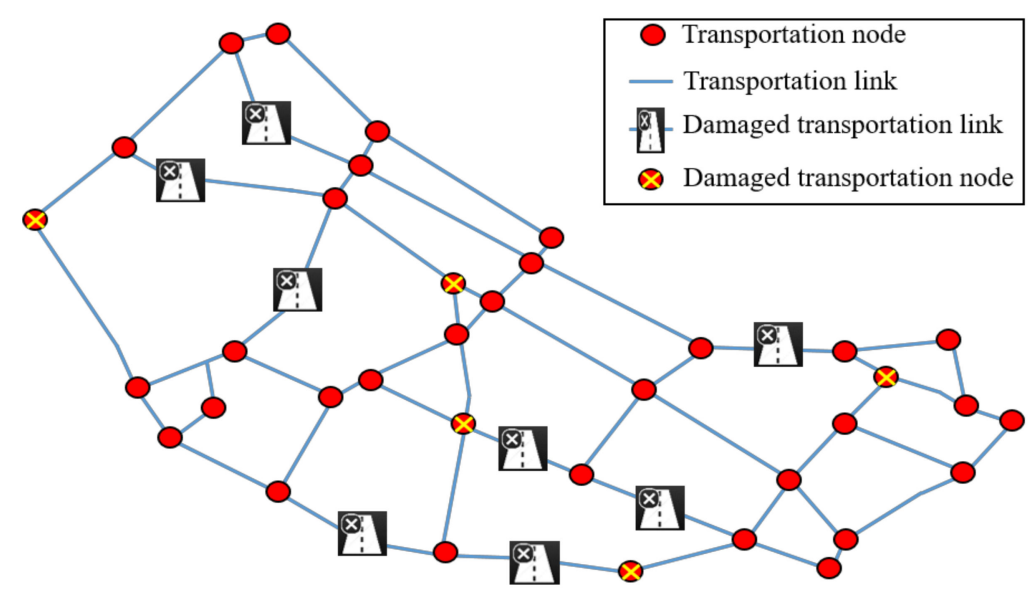

Figure 6. Road network sample including links and nodes affected by seismic events.

\subsection{Methods for Network Vulnerability Assessment}

In order to assess the impact of seismic damage to certain links or nodes on the functionality of the road network, a number of approaches were applied. Taylor [114] differentiated and provided a relationship between reliability and vulnerability of the road network, with vulnerability being considered more important than reliability when dealing with major impacts of the transport network such as social and economic degradation. Accordingly, the vulnerability of the road network is linked to the failure of the elements critical to that network. One of the first attempts is attributed to Berdica [115], who defined the vulnerability of the road network as the susceptibility to events that can lead to various deficiencies in the serviceability of road networks. In addition, D'Este and Taylor [116] introduced a new approach to assess the vulnerability of road networks by performing an accessibility analysis based on two criteria: (i) a node is considered vulnerable if the loss or substantial degradation of a small number of links reduces the accessibility of the node; (ii) the link is considered critical if the loss of a particular link reduces the accessibility of the network.

\subsubsection{Accessibility Index}

The vulnerability of the road network is assessed on the basis of the quality of accessibility between the nodes. Relative accessibility is the connection between two different points, which can be evaluated using different terms such as distance, travel costs, and travel time. Relative accessibility is mainly used to determine ease of transport to critical facilities places such as emergency centers, hospitals, and police stations, by which the ease of transport can be assessed on the basis of the degree of connection between origin and destination [116]. 
Different methods for calculating accessibility have been established, based on different factors and scales of analysis. These include accessibility, place-accessibility, individuallevel analysis, and areal analysis [117]. The first accessibility index that was introduced is the Hansen index, which includes the spatial separation coefficients and supply demand coefficients [118].

D'Este and Taylor [116] introduced the accessibility index of road networks by using the integral accessibility approach of Black and Conroy [119], which investigates the connection between different nodes and activities in a given region. In addition, Chang [117] formulated an indicator to measure the accessibility performance of the network $D$, for specific spatial units $S$, at a particular time $t$ after an earthquake. The value of this index ranges from 0 (no accessibility) to 1 (full accessibility). If a particular link breaks or fails, a measure of vulnerability is generated, defined as the cost of transport between two separate nodes, which is resulting from the variation of travel distance, travel time, and travel costs [120]. Nevertheless, Luathep et al. [121] assessed vulnerability of the road network, by conducting a sensitivity analysis (SA) to evaluate the accessibility. The SA approach is mainly used to improve the conducted results by increasing the computational efficiency. This method is based on the accessibility index proposed by Taylor [114] and integrated with the Hansen integral index [122]. The result of this method is considered to be the normal accessibility index, which is symbolized by $A I^{\text {Normal }}$. An approximation for the accessibility index was then performed, which led to the degraded accessibility index $A I^{\text {degraded }}$. The Jacobian of the normal accessibility index and Taylor index [114] is performed using SA. For further details, refer to Luathep et al. [121].

The assessment of road network accessibility requires the processing of a large amount of spatial data, and thus, GIS technology provides useful spatial analysis tools and methods, which are described in the following.

Ertuğay et al. [123] investigated the probabilistic models used to study the accessibility of road networks using GIS and to determine the probability of road closures in a given road network. Accessibility in the model is based on a zoning approach; the main advantage of this approach is the comparison between different zones based on different accessibility scores (zone-based method). Mainly, the method is conducted by evaluating the cumulative cost between time and distance, which can be formulated by referring to the centroid of the main services in each zone.

Another approach used to assess accessibility based on GIS is the isochrone-based method, which studies the main boundaries of important service areas by evaluating and connecting equal average travel time and distance points away from one or more specific points. When the origin is specified as the main reference point (demand/supply location), isochronal boundaries are conducted by connecting different points in all directions in terms of time or distance or equal threshold [123-127].

The third method is the raster-based method, which is represented with pixels or cells, which present the accessibility values. The raster pixels is considered the smallest entity in the raster environment, which gives a specific accessibility score, depending on the closest proximity to the supply/demand node [123,128-131].

Each method has specific advantages and disadvantages. For instance, in regional studies, the Raster-based approach is preferred over other methods, because it does not require advanced spatial accuracy. This method results in different representations of accessibility scores, which leads to a variety of advanced capabilities. However, the isochrone-based method is preferred mainly because of the efficient representation of important service and catchment areas. Although this approach is widely used, its weakness is its sensitivity to travel time, distance costs, and user-defined thresholds. Finally, the zone-based method has advantages over the two other methods. This is because this method compares the accessibility score between zones in a simplified way; however, it is complicated to obtain the required data for small zones than coarse zones [132]. 


\subsubsection{Link Importance Index}

The assessment of VI for road networks is divided into two main categories. The first category is related to travel-cost vulnerability measures (distance-based methods), while the second is related to the cost vulnerability measures (cost-based methods) [133]. The link between different nodes in the road network forms a cluster. A link is considered critical if the loss of this link impairs the functionality of the road network [134]. Different approaches were employed to study the criticality of links and their effect on road networks.

Taylor et al. [135] investigated the effect of the loss of a certain link on the functionality of the road network. The study defined a cost factor that results from a specific combination of distance and time. The index $T_{a}$ evaluates the variation in costs between two different scenarios. In the first scenario the link is intact, while in the second scenario the link is removed. Nagurney and Qiang [136] assessed the link importance index (LI) by performing an efficiency measurement for networks with a specific network topology $G$ and origindestination demand Q. Furthermore, Jenelius et al. [137] formulated an importance index by studying the importance of a specific non-cut link symbolized by the letter a, through which the cut-link increases the cost of travel and leads to a finite increase for the whole network. Scott et al. [138] developed a network robustness index (NRI) for networks, based on the volume of discrete links, taking into account redirection options for OD pair in these links. The method then considered the travel time to measure the redirection cost, when a link is completely removed. An assumption is built upon the complete closure of a specific link, by which the users could follow the user-equilibrium in route options. Finally, the travel costs for the network with all the intact links are calculated (base case). The difference between the two scenarios is performed and results in NRI.

Balijepalli and Oppong [133] introduced a new vulnerability index (NVI) to examine the criticality of links in the network. The NVI studies the importance of each link in the road network by considering the serviceability of that link. In addition, the NVI works efficiently in evaluating the system in case of partial degradation for a specific link, resulting in different scenarios with different results. The serviceability of the link is obtained by dividing the available capacity for the link by the maximum hourly capacity per lane for a given road type. The capacity of a single link is calculated by summing the capacities of available operational lanes. The hourly capacities are specified according to DfT Transport Analysis Guidance [139]. Finally, the value of $r$ represents a reduction factor for the available capacities in case of multiple hazards [133]. Nevertheless, Rupi et al. [140] introduced LI to evaluate the criticality of links in road network, by conducting a case study in Bolzano, northern Italy, where the LI depends on two main aspects: usage level and closure impact on the entire road network, which range from zero to one. LI was formulated by studying the local and global significance.

In addition, Gecchele et al. [141] used LI to analyze the vulnerability of road networks by introducing two new measures for the local, $F\left(A D T_{e}\right)$ and $G\left(\Delta C_{e}\right)$, which are defined in Equations (8) and (9).

$$
F\left(A D T_{e}\right)=\frac{D T_{e}-D T_{\min }}{D T_{\max }-D T_{\min }}
$$

where $D T_{e}$ is the daily traffic $(D T)$ for a given link and $D T_{\max }$ and $D T_{\min }$ are the maximum and minimum $D T$ values, respectively.

$$
G\left(\Delta C_{e}\right)=\frac{g_{e}-g_{\min }}{g_{\max }-g_{\min }}
$$

where $g_{\max }$ and $g_{\min }$ are the maximum and minimum values of $g_{e}$ calculated for the set of links in road network, by which $g_{e}$ is defined as shown in Equation (10):

$$
g_{e}=\Delta C_{e}+\alpha d_{i j}^{e}
$$


where $\Delta C_{e}$ represents the total variation in travel time after the closure of link e; $d_{i j}^{e}$ is the unsatisfied demand from $i$ to $j$; and $\alpha$ is coefficient calculated with respect to link (cut or non-cut link).

Additionally, Chen et al. [142] proposed a vulnerability index to evaluate the effect of link closure on the surrounding area instead of the entire road network. The impact on the surrounding area if a specific link is closed is evaluated by the vulnerability index $V U L_{a}^{1}$ (relative change in network efficiency). The network efficiency of the affected area is developed based on Latora and Marchiori [143], with modifications by Chen et al. [142] and the performance measure $E(G)$ shown in Equation (11).

$$
E(G)=\frac{\sum_{i} \sum_{r s} \frac{u^{r s} q_{r s}}{\pi_{i}^{r s}}}{\sum_{r s} q_{r s}}, \forall_{r s} \in R S, \forall_{i} \in I
$$

where $q_{r s}$ is mean travel demand between O-D nodes; $u^{r s} \mathrm{i}$ is the proportion of type $i$ travelers traveling from $r$ to $s$; and $\pi_{i}^{r s}$ is minimum travel time budget between the O-D pair for type $i$ travelers.

Li et al. [144] introduced a new approach to assess the criticality of links in the road network. This method used the traffic flow betweenness index (TFBI) to identify the most critical links. This approach assumes different scenarios with different link disruptions, which leads to a time-consuming, prohibitive procedure.

Other studies introduced different methods to assess the vulnerability of road networks by identifying the criticality of links. For example, Rehak et al. [145] introduced the cascading impact assessment method (CIA) to identify the most critical links. Vodak et al. [146] studied the criticality by formulating a rapid deterministic algorithm. Furthermore, Zhang et al. [134] focused on characteristics that are highly correlated for traffic flow in order to create a verification method, capable of specifying the most critical links in road network.

The vulnerability assessment is mainly based on two measures, the travel distance and travel time. Vulnerability indices based on distance work efficiently for scattered regional networks. However, they are less suitable for urban networks, as travelers in urban networks weight the travel time more than travel distance. Moreover, the VI that is related to OD cost assumes that all traffic in scattered regional networks tends to travel through the routes with the least cost. Therefore, while driver travel on different routes in the urban network, all of these routes are considered important [133]. Furthermore, other indices are based on computational methods that can be helpful in studying the vulnerability of larger and more complex networks, such as the cascading impact assessment method and the rapid deterministic algorithm method. After assessing the vulnerability of road networks, a road network map with prioritized links is produced, taking into account different scenarios of link failure.

An overview of the available methods for assessing network vulnerability is presented in Table 13, including indices, parameters, and type of method.

Table 13. Existing methods for network vulnerability assessment.

\begin{tabular}{ccc}
\hline $\begin{array}{c}\text { Vulnerability } \\
\text { Assessment Method }\end{array}$ & Equation & Parameters \\
\hline Accessibility index & $A I=\sum_{j} B_{j} f\left(C_{i j}\right) / \sum_{j} B_{j}$ & $f\left(C_{i j}\right):$ Impedance function. \\
& & $B_{j}:$ the intensity of an activity at $j$. \\
\hline Accessibility index & $D_{s, t}=\frac{f-R_{s, t}}{f-1}$ & $\begin{array}{c}R_{s, t} \text { Transport accessibility ratio of } \\
\text { spatial unit } s \text { at a specific time } t . \\
f: \text { Constant (effective distance } \\
\text { multiplayer). }\end{array}$ \\
\hline
\end{tabular}


Table 13. Cont.

\begin{tabular}{|c|c|c|c|}
\hline $\begin{array}{c}\text { Vulnerability } \\
\text { Assessment Method }\end{array}$ & Equation & Parameters & Reference \\
\hline Accessibility index & $A I_{i}(T)=\int_{0}^{T} N_{i}(t) d t$ & $\begin{array}{c}A I_{i}(T) \text { : Cumulative number of } \\
\text { opportunities within } T \text { travel cost units } \\
\quad \text { from location } i \text {. } \\
N_{i}(t): \text { Absolute number of opportunities } \\
\text { at } t \text { travel cost units from } i \text {. }\end{array}$ & [116] \\
\hline $\begin{array}{l}\text { Link importance } \\
\text { index }\end{array}$ & $\operatorname{Importance}(a)=\frac{\sum_{k} w_{k} \Delta_{k a}^{-}}{\sum_{k} w_{k}}$ & $\begin{array}{l}w_{k}: \text { Weight specified for OD pair } k \text { that } \\
\text { reflects its importance by } \overline{\Delta_{k a}}=-\Delta_{k a} .\end{array}$ & [135] \\
\hline $\begin{array}{l}\text { Network robustness } \\
\text { index }\end{array}$ & $N R I_{a}=\tilde{C}_{a}-C$ & $\begin{array}{l}\tilde{C}_{a}: \text { Represent the total travel cost for } \\
\text { network when link }(a) \text { is detached. } \\
C: \text { Evaluated cost for the base cost when } \\
\text { all links are in the network are intact } \\
\qquad\left(C=\sum_{s} t_{s} x_{S}\right) .\end{array}$ & [138] \\
\hline $\begin{array}{l}\text { Link importance } \\
\text { index }\end{array}$ & $T_{a}=\sum_{k} q_{k} \Delta c_{k a}$ & $\begin{array}{c}q_{k}: \text { Travel demand. } \\
\Delta c_{k a}: \text { Change in generalized cost for } \\
\text { origin demand (OD) pair } k \text { when link } a \\
\text { fails. }\end{array}$ & [135] \\
\hline $\begin{array}{l}\text { Link importance } \\
\text { efficiency measure }\end{array}$ & $\varepsilon(G, Q)=\sum_{k} \frac{q_{k}}{c_{k}} / n_{k}$ & $\begin{array}{c}c_{k}: \text { Cost of OD pairs. } \\
n_{k}: \text { Number of the OD pairs. }\end{array}$ & [136] \\
\hline Accessibility index & $A I=\frac{\sum_{w \in W} q^{w} \cdot A I^{w}}{\sum_{w \in W} q^{w}}$ & $\begin{array}{c}q^{w}: \text { Travel demand of OD movement } \\
w \in W . \\
A I^{w}: \text { Accessibility index. }\end{array}$ & [114] \\
\hline $\begin{array}{l}\text { Accessibility index } \\
\text { (sensitivity analysis) }\end{array}$ & $A I^{\text {degraded }} \approx A I^{\text {normal }}+\left.\nabla_{s} A I^{\text {normal }}\right|_{s_{0}} \cdot s^{T}$ & $\begin{array}{c}\left.\nabla_{s} A I^{\text {normal }}\right|_{s_{0}} \text { Jacobian of the normal } \\
\text { accessibility index with respect to vector } \\
\text { of link capacity degradations at initial } \\
\text { state. }\end{array}$ & [121] \\
\hline Accessibility loss & $V_{r s}=\sum_{i} \sum_{j} d_{i j} v_{i j r s}$ & $\begin{array}{l}d_{i j}: \text { Movement between } i \text { and } j . \\
v_{i j r s} \text { : Difference of the generalized cost } \\
\text { of transportation between node } i \text { and } j \text {. }\end{array}$ & [120] \\
\hline $\begin{array}{c}\text { Network } \\
\text { vulnerability index }\end{array}$ & $V U L_{a}^{1}=\frac{E_{0}\left(G_{a}\right)-E_{a}\left(G_{a}\right)}{E_{0}\left(G_{a}\right)}$ & $\begin{array}{c}E_{0}\left(G_{a}\right) \text { and } E_{a}\left(G_{a}\right): \text { Network efficiency } \\
\text { of impacted area } G_{a} \text { under two different } \\
\text { scenarios (normal condition and during } \\
\text { closure of link } a \text { ). }\end{array}$ & [142] \\
\hline $\begin{array}{c}\text { Network } \\
\text { vulnerability index }\end{array}$ & $N V I=\sum_{i=1}^{|A|}\left[\left(\frac{x_{i}^{\text {before }}}{r_{i}^{\text {before }}} t_{i}^{\text {before }}\right)\right]-\sum_{i=1}^{|A|}\left[\left(\frac{x_{i}^{\text {after }}}{r_{i}^{\text {after }}} t_{i}^{\text {after }}\right)\right]$ & $\begin{array}{c}r_{i}: \text { Link serviceability } i . \\
|A|: \text { number of specified links in the } \\
\text { network. }\end{array}$ & [133] \\
\hline $\begin{array}{l}\text { Link importance } \\
\text { index }\end{array}$ & $L I(j)=k \cdot F\left(A D T_{j}\right)+(1-k) \cdot G\left(\Delta C_{j}\right)$ & $\begin{array}{l}F: \text { is the function that is related to } A D T_{j} \text {. } \\
\text { G: function that is related to } \Delta C_{j} . K: \\
\text { calibration coefficient. }\end{array}$ & [140] \\
\hline $\begin{array}{l}\text { Accessibility index } \\
\text { (zone-based } \\
\text { approach) }\end{array}$ & $A_{i}=\sum_{j} \frac{1}{\text { time or distance }(i, j)}$ & $\begin{array}{c}A_{i}: \text { Accessibility score for origins. } \\
i \text { : Origin. } \\
j: \text { Destination. }\end{array}$ & [123] \\
\hline $\begin{array}{l}\text { Accessibility index } \\
\text { (zone-based } \\
\text { approach) }\end{array}$ & $A_{i}=\sum_{j} \frac{G(j)}{\text { time or distance }(i, j)}$ & $\begin{array}{l}G(j): \text { Gravity measure of specific service } \\
\text { in the road-network. }\end{array}$ & [123] \\
\hline $\begin{array}{c}\text { Traffic flow } \\
\text { betweenness index }\end{array}$ & $T F B I_{a}=\left[\left(T F B_{a}\right)_{n o r}\right]^{r} \cdot\left[\left(d_{s t}\right)_{n o r}\right]^{1-r}$ & $\begin{array}{c}d_{s t} \text { : Endpoint for OD demand; it } \\
\text { represents the affected demand caused } \\
\text { by the closure of link } a \text {. } \\
T F B_{a}: \text { Traffic flow betweenness for a } \\
\text { specific defined link } a \text {. } \\
r \text { : Coefficient used to allocate weights } \\
\text { between }\left(T F B_{a}\right)_{\text {nor }} \text { and }\left(d_{s t}\right)_{\text {nor }} \text {. }\end{array}$ & [144] \\
\hline
\end{tabular}




\section{Integrated Seismic Risk Assessment for Road Network System}

Although damage of road networks as a result of earthquakes cannot be accurately predicted, there is a precautionary process, i.e., a risk assessment of the road network, that could help in the mitigation and adaptation process by infrastructure owners and stakeholders to decrease the disruptions in the event of an earthquake. A pre-earthquake study is therefore essential to assess the performance of each road. An accurate assessment of the seismic hazard estimation is a key challenge to be addressed in this process. This is due to the fact that a road network, as opposed to a single structure where the risk is sitespecific, spans over a large region, which can lead to higher impact of the natural disaster. Moreover, the risk assessment is more challenging, as the different network assets are exposed to different levels of seismic hazard and variable geotechnical conditions [38,147].

Most of the available models focus mainly on a single criterion, e.g., physical damage to road assets, traffic disruption, and/or functionality of the road network. However, the correlation between damage to assets and network functionality by risk assessment models that focus on multi criteria aspects are limited. In addition, specifying the seismic performance considering the road network functionality is an essential step toward improving the resilience of the transport infrastructure [148,149].

For all the above reasons, a comprehensive integrated model for risk assessment of the road network needs to be implemented. This model will be able to assess and evaluate all the above-mentioned critical consequences and to specify the seismic performance of road networks. A number of studies and methods based on different integration approaches are currently available.

\subsection{Methods Considering Uncertainties (Probabilistic Models)}

Tang and Huang [150] assessed the seismic vulnerability of road networks based on a Bayesian network approach, which considers bridges and roads as the main components. The model was developed on the area that is centering Shunhe Hui District and the Baogong Lake in China. The model focused on connectivity as a seismic vulnerability index (VI) to assess the serviceability of the network in case of earthquakes. In addition to O-D connectivity, the capacity of the network depends on the integrity of its segments. Yet, there is uncertainty in the seismic hazard, as well as in the evaluation of demand and capacity of the road elements; hence, probabilistic methods are commonly adopted to treat uncertainties. Moreover, seismic vulnerability of each component (road segments and bridges) is examined prior to the road network vulnerability assessment. Eventually, the Bayesian network method is considered important in reducing uncertainties, and it was used extensively before in fields of safety management and risk assessment [151-153].

Costa et al. [154] developed a probabilistic approach to study the impact of earthquakes on road traffic by studying the correlation between the physical damage of road assets and traffic flow on road networks in Messina, Italy. A probabilistic approach was employed to account for the spatial variation of earthquake-induced damages. This research investigated the functionality of road network by comparing the traffic behavior of the road network in normal conditions and in case of disruptions caused by building debris.

Although the physical damage of road networks is a crucial part for developing the VI, the main problem arising from this physical damage is the reduced accessibility and serviceability [115]. Therefore, in the vulnerability assessment, a combination of damage, traffic, and functionality should be considered for both road network and its system of assets.

\subsection{Traffic Flow Analysis Methods}

A frequently applied approach is the sensitivity analysis method [155]: this model is used to assess road network vulnerability from the capacity degradation aspect; it is considered more efficient than the traditional assignment method (traffic assignment). Thus, the analytical performance is greatly improved, and the vulnerability of the actual large road network can be analyzed more efficiently. Additionally, the model conducted 
the route vulnerability models and origin-destination (OD) pair based on road segments by applying a weighted arithmetic average. The OD matrix presents a model that yields the most likely origin-destination matrix that is consistent with measurements of link traffic volumes [156]. Jin et al. [157] assessed the seismic risk by studying the vulnerability of road networks using non-structural components. The model considered the increment of travel time costs that resulted from different negative consequences. The aim of this model is to test the vulnerability of the road network that becomes sensitive to internal and external strains without taking into consideration the structural disruption. Nevertheless, Khademi et al. [158] employed a binary OD matrix model to analyze the vulnerability of Tehran road networks in Iran. This research proposes a method to investigate post-earthquake responsive and recovered routes through identification of isolation measures (distance between nodes and the type of trips), which are based on redundancy. These measures can help in determining the most susceptible roads to disruption during earthquake. For instance, as the distance increases between two nodes, more redundant paths will be implied, but when the distance decreases, less redundant paths will be available, making this node more isolated. The study aims to identify which areas in the road network are the most vulnerable to disruptions caused by major earthquakes.

Other researchers provided seismic risk assessment and studied seismic vulnerability performance for road networks using different methods. For instance, Liu et al. [159] established a new theory by using a system-thinking method to analyze the vulnerability of road networks. Cai et al. [160] performed vulnerability analysis for the subway network by investigating two different models: a generalized travel time model with capacity constraint and a logit based equilibrium model for path choice. Bílová et al. [161] investigated six sites in the Czech Republic that were severely damaged due to earthquakes and used two indexes, the network efficiency index and weighed network efficiency index, to identify the number of damaged roads, which are investigated using computational-time demand models. The network efficiency index $V_{t}$ is calculated based on an approach called closeness centrality, which compares the average efficiency of the damaged network with average efficiency of the undamaged road network. However, the weighted network efficiency index is evaluated according to the importance of each node in a road network [135].

\subsection{Connectivity Analysis Methods}

Argyroudis et al. [51] conducted an integrated method for analyzing the systematic risk of road networks. This research used a global connectivity indicator to investigate the road network performance. The connectivity performance indicator is evaluated through the relation between the physical damages and functional losses caused by interaction with other systems. Furthermore, Caiado et al. [162] formulated an approach, based on three main dimensions, to evaluate and strengthen the resiliency of urban networks. Those three dimensions are network connectivity, land use, and specific demand patterns for transportation. Finally, an accurate seismic risk assessment is considered as a complex task, due to variety of factors involved. In addition, vulnerability is taken into account as a main factor in this process alongside other factors. In general, the performance of road networks is commonly evaluated by using a single criterion model. However, a proper and accurate risk assessment for road networks requires an appropriate model that integrates damage, traffic, and functionality [163-165].

\subsection{Methods Considering Socioeconomic Factors}

Mainly, the integration approach is considered more effective in determining road network vulnerability, as it tests various parameters and their impact on each other. The integration can be done for studying different parameters and their effect on each other [166]. For instance, Kilanitis and Sextos [96] studied the functionality of a road network considering the economic and environmental consequences. Furthermore, Shinozuka et al. [167] investigated the effect of retrofitted bridges on road networks, by developing a probabilistic model to estimate and compare the economic losses before and after seismic retrofit of the 
bridges. The benefit of the retrofitting measures are assessed based on the drivers' delay index.

Duzgun et al. [168] assessed the vulnerability of urban areas based on a model, which integrated socio-economic impacts, structural vulnerabilities, structural characteristics of the ground condition, and accessibility to important services. In this study, a socioeconomic index was developed including demographic, socio-economic, social security, socio-spatial, political, and behavioral dimension aspects. This model was formulated by following four main steps, which are selection of samples and questionnaire formation, development of clusters and indicators, measurement analysis and assigning of the indicators, and formulation of socio-economic index. The study indicated that the socio-economic index could help in specifying and prioritizing the most vulnerable areas, by which more effective vulnerability reduction criteria can be implemented.

Nevertheless, Yang and Frangopol [169] investigated the deterioration of coastal bridges due to hurricanes addressing climatic and socio-economic variations. A model was built to study the effect of socioeconomic growth on life-cycle risks for coastal bridges, considering indirect economic costs due to bridge failure, which are the cost due to extra travelled time and distance per one car $C_{\text {time }}$ and $C_{\text {run }}$. The model accounts for the variation of travel time and average daily traffic (ADT) between normal circumstances and after hurricanes. Moreover, Kiremidjian et al. [170] formulated a model to evaluate the losses due to earthquakes, landslides, and liquefaction. Losses were represented by the repair costs of bridges as a measure of direct seismic losses.

\subsection{Holistic Vulnerability Analysis Methods}

These models investigate the urban system as a whole by integrating all its components (physical, economic, and social). Rus et al. [171] introduced a holistic concept considering four main components: buildings, community, open space, and infrastructure. This concept employed (i) probabilistic fragility functions for the individual physical components, (ii) a composite index approach for evaluating the resilience of the community against disasters, and iii) a complex network methodology (graph theory) to assess of the systemic resiliency. Nevertheless, Sevilla et al. [172] developed a holistic resilience assessment platform (HRAP) that provides an advanced environmental simulation for different potential impacts due to multi-hazards. This holistic platform provides an improved understanding of the performance of infrastructure and system of assets exposed to multi-hazards by evaluating interdependencies due to cascade failures and building up efficient risk-based response criteria for different scenarios.

Additionally, vulnerability assessment mainly helps to obtain big data analytics for better implementation of natural disaster security measures and resilience-based solutions. With the increase interest of the internet of things (IoT), applications nowadays are considered smarter with better connectivity aspects, making them beneficial in building sustainable and resilient city infrastructure. Additionally, machine learning (ML) approaches can significantly improve the efficiency of transport models based on prediction models such as the Bayesian method, Markov model, clustering method, artificial neural networks, or regression analysis. These solutions can reduce the number of injuries and accidents [173-176]. Eventually, different integrated models should be developed, through the use of ML approaches, to increase the efficiency of the methods used for assessment of vulnerability for road networks. Additionally, different open-source simulation tools for traffic analysis are being used. For instance, Costa et al. [154] used the Simulation of Urban Mobility (SUMO) tool to conduct the traffic simulations; in this tool different specifications can be inserted to define the network, such as geometric specifications, speed limits, and any junctions or traffic lights. Nevertheless, Van noort et al. [177] developed an integrated traffic simulation platform (MOBYSIM) that takes into account the interaction between vehicles and the surrounding environment, which can help in determining the road network performance for three different aspects: efficiency, the environment, and safety. 
Moreover, monitoring-enhanced resilience has not been completely investigated yet. Digital technologies have the ability to yield rapid resilience assessments for transport infrastructure exposed to natural and human induced hazards within its life cycle. For instance, remote sensing, which uses space-borne and air-borne imaging platforms, provides the main merits of broad spatial coverage in the absence of any means of assessment for the infrastructure performance or functionality. In addition, satellite images can provide rapid vulnerability assessment maps for larger geographic areas $[39,172,177]$. Finally, different technologies are being used to monitor and assess the vulnerability and the traffic conditions of transport infrastructure. These technologies can provide valuable information and improve the available vulnerability models as well as the phases of resilience (preparation, response and recovery, mitigation). An improved integrated network vulnerability model is proposed in this literature review (Figure 7), which integrates two main different assessment approaches (physical damage and traffic disruption assessment approach). Although the focus here is on seismic hazard effects, this integrated approach is also applicable to other hazards.

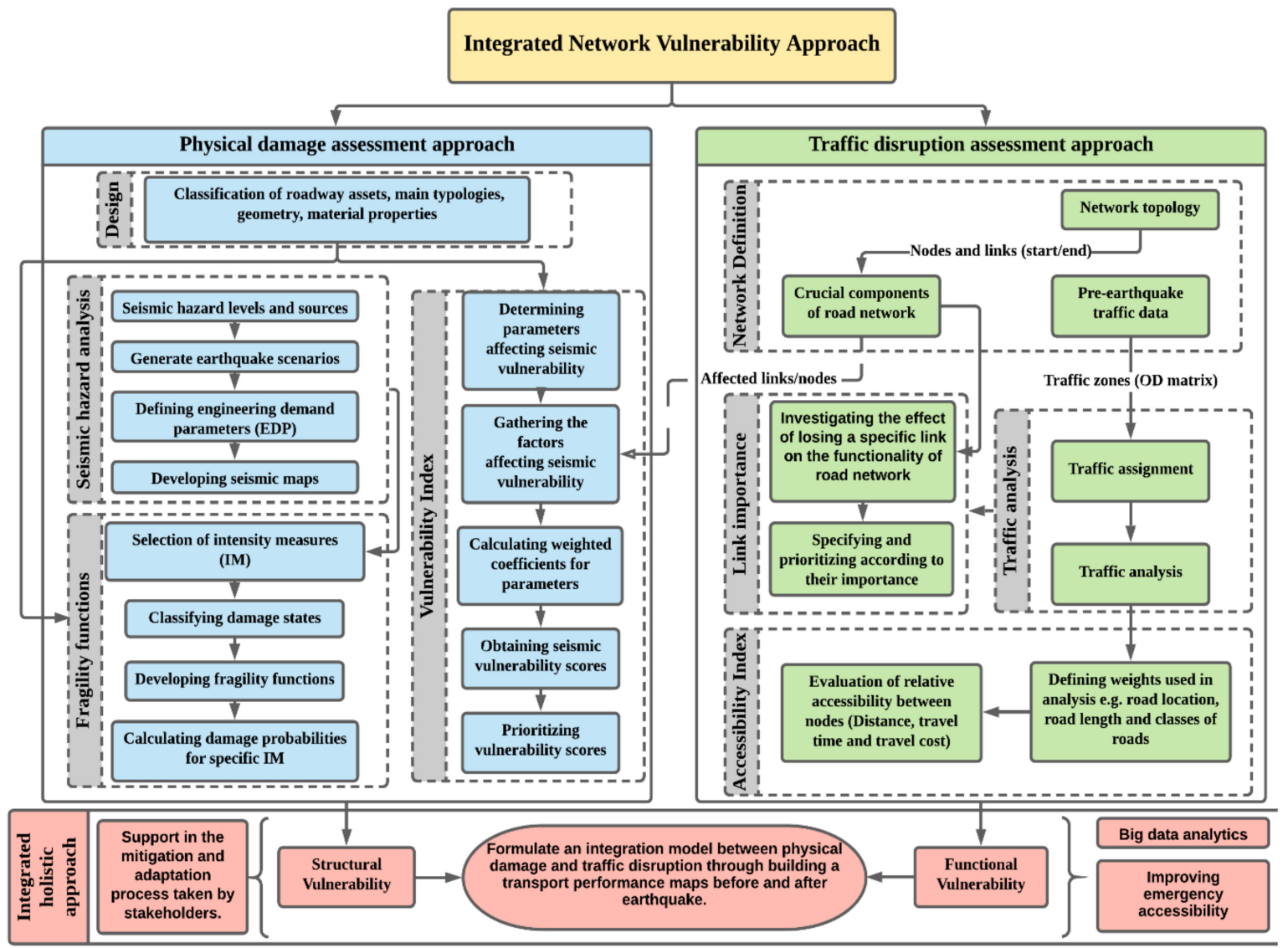

Figure 7. Proposed integrated network vulnerability approach.

\section{Conclusions}

The vulnerability assessment of critical infrastructure has gained great attention in the last decades due to its great importance in natural disasters. Vulnerability assessment is a key step for adaptation and improvement of the resiliency of road networks, to continue their function under hazard events. This literature review aimed to present the methods that are used in assessing the vulnerability of road networks and their assets, focusing on seismic hazard. At first, this paper presented the two main categories of vulnerability assessment, the ones based on fragility functions and the vulnerability index (VI) methods. In the fragility functions, four different approaches are used: empirical, analytical, expertjudgment, and hybrid. The empirical and expert-judgment approaches can be insufficient 
and, in some cases, less accurate compared to the hybrid and analytical counterparts. However, the available hybrid and analytical based fragility models for road pavements and slopes are limited. The VI methods are more efficient for road networks compared to fragility curve methods due to their capability to tackle a set of road segments in a specific network. Moreover, the VI method is considered important in rating and prioritization of assets. However, the variability of data regarding the vulnerability parameters and their weighting scores makes it difficult to formulate a common VI approach.

Subsequently, this paper explored two main methods for assessing the vulnerability of road networks, the accessibility index, and the link importance index; these methods evaluate the functionality of the road network with respect to the analyzed traffic. The accessibility index is based on GIS techniques to obtain results that are more efficient and practical, particularly in regional and complex road networks compared to the accessibility indices. However, this model is data-dependent with respect to other models. On the other hand, the link importance index is based on two main measures, the travel time and travel distance. The travel time measurement is considered more efficient for studying urban road networks, while travel distance-based is more adequate in case of regional networks. Most of the vulnerability assessment studies focus on a single criterion without considering the integration between different attributes. Therefore, more comprehensive models such as integrated seismic risk assessment should be formulated and validated in future studies. Conducting accurate integrated seismic risk assessment is a complex task due to the large number of variables. However, a more reliable risk assessment for road networks requires a model that integrates damage, traffic, and functionality. Therefore, integrated seismic risk assessment methodologies were investigated in the last part of this paper, including probabilistic models, traffic flow analysis methods, methods considering socioeconomic factors, connectivity analysis methods, and holistic vulnerability analysis methods.

In summary, considerable efforts have been made to develop either physical approaches or traffic analysis-based approaches, in order to study the vulnerability of road networks and their assets. The focus of future research should be on the testing of the different methods in real-life settings and on the development of integrated systems that will in turn show us the interrelations between all components of the road networks. A main factor for such effort would be the integration of the physical based approach with the traffic analysis. In addition to that, another important factor that should be further investigated is the system of assets under the effect of multi-hazards. Formulating an integrated assessment model is considered complex, yet an important approach that should be followed in assessment of road network vulnerability and its assets. Indeed, the new emerging and digital technologies are considered the ideals for development of these integrated models in the future. In this respect, a holistic model forms the foundation for the shift that is needed in formulation of more efficient integrated assessment approaches in the research field.

Author Contributions: Conceptualization and methodology: A.M.E.-M. and F.M.N.; writingoriginal draft preparation: A.M.E.-M. and F.M.N.; writing-review and editing: S.A.A.; visualization: A.M.E.-M.; supervision: F.M.N. and S.A.A. All authors have read and agreed to the published version of the manuscript.

Funding: This research was supported by Ministry of Education (MOE) through Fundamental Research Grant Scheme (FRGS/1/2020/TK02/USM/02/1).

Conflicts of Interest: The authors declare no conflict of interest.

\section{References}

1. Ivanova, E.; Masarova, J. Importance of road infrastructure in the economic development and competitiveness. Econ. Manag. 2013, 18, 263-274. [CrossRef]

2. Vandycke, N.L.; Care Baptista Viegas, J.M.; Morales Sarriera, J. Global Roadmap of Action Toward Sustainable Mobility; The World Bank: Washington, DC, USA, 2019. 
3. Koks, E.E.; Rozenberg, J.; Zorn, C.; Tariverdi, M.; Vousdoukas, M.; Fraser, S.; Hall, J.; Hallegatte, S. A global multi-hazard risk analysis of road and railway infrastructure assets. Nat. Commun. 2019, 10,1-11. [CrossRef] [PubMed]

4. Alizadeh, H.; Sharifi, A. Assessing Resilience of Urban Critical Infrastructure Networks: A Case Study of Ahvaz, Iran. Sustainability 2020, 12, 3691. [CrossRef]

5. Tsakalidis, A.; Gkoumas, K.; Pekár, F. Digital Transformation Supporting Transport Decarbonisation: Technological Developments in EU-Funded Research and Innovation. Sustainability 2020, 12, 3762. [CrossRef]

6. United Nations. The Sustainable Development Goals Report 2020; United Nations: New York, NY, USA, 2020.

7. National Academies of Sciences, Engineering and Medicine. A Review of the Citrus greening Research and Development Efforts Supported by the Citrus Research and Development Foundation: Fighting a Ravaging Disease; National Academies Press: Washington, DC, USA, 2018.

8. Rozenberg, J.; Espinet Alegre, X.; Avner, P.; Fox, C.; Hallegatte, S.; Koks, E.; Rentschler, J.; Tariverdi, M. From A Rocky Road to Smooth Sailing: Building Transport. Resilience to Natural Disasters; World Bank: Washington, DC, USA, 2019.

9. Winter, M.G.; Peeling, D.; Palmer, D.; Peeling, J. Economic impacts of landslides and floods on a road network. Auc. Geogr. 2019, 54, 207-220. [CrossRef]

10. Winter, M.; Bromhead, E. Landslide risk: Some issues that determine societal acceptance. Nat. Hazards 2012, 62, 169-187. [CrossRef]

11. Eeri, T. Loma Prieta earthquake reconnaissance report. Earthq. Spectra 1990, 127-149.

12. Stover, C.W.; Coffman, J.L. Seismicity of the United States, 1568-1989 (Revised); US Government Printing Office: Washington, DC, USA, 1993.

13. French, S.P. Damage to urban infrastructure and other public property from the 1989 Loma Prieta (California) earthquake. Disasters 1995, 19, 57-67. [CrossRef]

14. Basoz, N.; Kiremidjian, A.S. Evaluation of Bridge Damage Data from the Loma Prieta and Northridge, California Earthquakes; MCEER: Buffalo, NY, USA, 1998.

15. Twiss, R.J.; Unruh, J.R. Structure, deformation, and strength of the Loma Prieta fault, Northern California, USA, as inferred from the 1989-1990 Loma Prieta aftershock sequence. Gsa Bull. 2007, 119, 1079-1106. [CrossRef]

16. Shinozuka, M. The Hanshin-Awaji earthquake of January 17, 1995 performance of lifelines. In Technical Report NCEER.; US National Center for Earthquake Engineering Research (NCEER): Buffalo, NY, USA, 1995; Volume 95.

17. Chang, S.E.; Nojima, N. Measuring post-disaster transportation system performance: The 1995 Kobe earthquake in comparative perspective. Transp. Res. Part A 2001, 35, 475-494. [CrossRef]

18. Nariyuki, Y.; Hirao, K.; Fukui, Y. In Discriminant Analysis of Street-Blockades in Kobe City due to the 1995 Hyogoken-Nanbu Earthquake. In Proceedings of the 13th World Conference on Earthquake Engineering, Vancouver, BC, Canada, 1-6 August 2004; pp. 1-6.

19. Yin, H.-Y.; Xu, L.-Q. Measuring the structural vulnerability of road network: A network efficiency perspective. J. Shanghai Jiaotong Univ. 2010, 15, 736-742. [CrossRef]

20. Okuyama, Y. The rise and fall of the Kobe economy from the 1995 earthquake. J. Disaster Res. 2015, 10, 635-640. [CrossRef]

21. Eeri, T. 1999 Kocaeri, Turkey, Earthquake Reconnaissance Report. Earthq. Spectra 2000, 16, 237-279.

22. Erdik, M. Report on 1999 Kocaeli and Düzce (Turkey) Earthquakes; Boğaziçi Üniversitesi, Kandilli Rasathanesi ve Deprem Araştirma Enstitüsü: Istanbul, Turkey, 2000.

23. Pamuk, A.; Kalkan, E.; Ling, H. Structural and geotechnical impacts of surface rupture on highway structures during recent earthquakes in Turkey. Soil Dyn. Earthq. Eng. 2005, 25, 581-589. [CrossRef]

24. Eeri, T. 1999 Chi-Chi, Taiwan, Earthquake Reconnaissance Report. Earthq. Spectra 2001, 17, 81-130.

25. Shin, T.-C.; Teng, T.-1. An overview of the 1999 Chi-Chi, Taiwan, earthquake. Bull. Seismol. Soc. Am. 2001, 91, 895-913. [CrossRef]

26. D'Amico, S.; Caccamo, D.; Parrillo, F.; Lagana, C.; Barbieri, F. The 20th September 1999 Chi-Chi earthquake (Taiwan): A case of study for its aftershock seismic sequence. Izv. Phys. Solid Earth 2010, 46, 317-326. [CrossRef]

27. Wang, F.; Cheng, Q.; Highland, L.; Miyajima, M.; Wang, H.; Yan, C. Preliminary investigation of some large landslides triggered by the 2008 Wenchuan earthquake, Sichuan Province, China. Landslides 2009, 6, 47-54. [CrossRef]

28. Xu, B. Consensus crisis and civil society: The Sichuan earthquake response and state-society relations. China J. 2014, 71, 91-108. [CrossRef]

29. Bray, J.; Frost, D. Geo-engineering reconnaissance of the 2010 Maule, Chile earthquake. Rep. No. Geer-022 Nsf Spons. Geer Assoc. Team 2010, 2, 1.

30. EERI. EERI Special Earthquake Report-June 2010: The Mw 8.8 Chile Earthquake of February 27, 2010. EERI Nezwsl. 2010, $28,1-20$.

31. Elnashai, A.S.; Gencturk, B.; Kwon, O.-S.; Al-Qadi, I.L.; Hashash, Y.; Roesler, J.R.; Kim, S.J.; Jeong, S.-H.; Dukes, J.; Valdivia, A. The Maule (Chile) Earthquake of February 27, 2010: Consequence Assessment and Case Studies; Mid-America Earthquake Center: Urbana, IL, USA, 2010.

32. Anbazhagan, P.; Srinivas, S.; Chandran, D. Classification of road damage due to earthquakes. Nat. Hazards 2012, 60, 425-460. [CrossRef]

33. Harith, N.; Adnan, A.; Tongkul, F.; Shoushtari, A. Analysis on earthquake databases of Sabah region and its application for seismic design. Int. J. Civ. Eng. Geo-Environ. 2017, 8, 1-5.

34. Tongkul, F. The 2015 Ranau Earthquake: Cause and impact. Sabah Soc. J. 2016, 32, 1-28. 
35. Wang, Y.; Wei, S.; Wang, X.; Lindsey, E.O.; Tongkul, F.; Tapponnier, P.; Bradley, K.; Chan, C.-H.; Hill, E.M.; Sieh, K. The 2015 M w 6.0 Mt. Kinabalu earthquake: An infrequent fault rupture within the Crocker fault system of East Malaysia. Geosci. Lett. 2017, 4, 1-12. [CrossRef]

36. Giovinazzi, S.; Nicholson, A. Transport network reliability in seismic risk analysis and management. In Proceedings of the 14th European Conference on Earthquake Engineering (14ECEE), Ohrid, North Macedonia, 30 August-3 September 2010.

37. Argyroudis, S.A.; Mitoulis, S.A.; Hofer, L.; Zanini, M.A.; Tubaldi, E.; Frangopol, D.M. Resilience assessment framework for critical infrastructure in a multi-hazard environment: Case study on transport assets. Sci. Total Environ. 2020, 714, 136854. [CrossRef]

38. Argyroudis, S.A.; Mitoulis, S.A.; Winter, M.G.; Kaynia, A.M. Fragility of transport assets exposed to multiple hazards: State-ofthe-art review toward infrastructural resilience. Reliab. Eng. Syst. Saf. 2019, 191, 106567. [CrossRef]

39. Achillopoulou, D.V.; Mitoulis, S.A.; Argyroudis, S.A.; Wang, Y. Monitoring of transport infrastructure exposed to multiple hazards: A roadmap for building resilience. Sci. Total Environ. 2020, 746, 141001. [CrossRef]

40. Argyroudis, S.; Kaynia, A.M. Fragility functions of highway and railway infrastructure. In SYNER-G: Typology Definition and Fragility Functions for Physical Elements at Seismic Risk; Springer: Berlin, Germany, 2014; pp. 299-326.

41. Pitilakis, K.; Argyroudis, S. Seismic vulnerability assessment: Lifelines. In Encyclopedia of Earthquake Engineering; Springer: Berlin/Heidelberg, Germany, 2014.

42. Papadopoulos, G.A.; Karastathis, V.K.; Ganas, A.; Pavlides, S.; Fokaefs, A.; Orfanogiannaki, K. The Lefkada, Ionian Sea (Greece), shock (Mw 6.2) of 14 August 2003. Earth Planets Space 2003, 55, 713-718. [CrossRef]

43. Kieffer, D.S.; Jibson, R.; Rathje, E.M.; Kelson, K. Landslides triggered by the 2004 Niigata ken Chuetsu, Japan, earthquake. Earthq. Spectra 2006, 22 (Suppl. 1), 47-73. [CrossRef]

44. Briggs, K.; Loveridge, F.; Glendinning, S. Failures in transport infrastructure embankments. Eng. Geol. 2017, $219,107-117$. [CrossRef]

45. Wang, J.; Li, Q.; Yang, C.; Zhou, C. Dynamic response and damage character of road embankment under strong earthquake. Int. J. Distrib. Sens. Netw. 2018, 14, 1550147718794611. [CrossRef]

46. Gehl, P.; D'Ayala, D. Integrated Multi-Hazard Framework for the Fragility Analysis of Roadway Bridges. In Proceedings of the 12th International Conference on Applications of Statistics and Probability in Civil Engineering (ICASP12), Vancouver, BC, Canada, 12-15 July 2015; pp. 12-15.

47. Kaynia, A.; Mayoral, J.; Johansson, J.; Argyroudis, S.; Pitilakis, K.; Anastasiadis, A. Fragility functions for roadway system elements. Syner-G Proj. Deliv. 2011, 109. Available online: http://www.vce.at/SYNER-G/files/dissemination/deliverables.html (accessed on 15 September 2020).

48. Sinha, R.; Shiradhonkar, S. In Seismic damage index for classification of structural damage-closing the loop. In Proceedings of the 15th World Conference on Earthquake Engineering, Lisboa, Portugal, 24-28 September 2012.

49. Argyroudis, S.; Mitoulis, S.; Kaynia, A.M.; Winter, M.G. Fragility assessment of transportation infrastructure systems subjected to earthquakes. In Geotechnical Earthquake Engineering and Soil Dynamics V: Numerical Modeling and Soil Structure Interaction; American Society of Civil Engineers: Reston, VA, USA, 2018; pp. 174-183.

50. Maruyama, Y.; Yamazaki, F.; Mizuno, K.; Tsuchiya, Y.; Yogai, H. Fragility curves for expressway embankments based on damage datasets after recent earthquakes in Japan. Soil Dyn. Earthq. Eng. 2010, 30, 1158-1167. [CrossRef]

51. Argyroudis, S.; Kaynia, A.M. Analytical seismic fragility functions for highway and railway embankments and cuts. Earthq. Eng. Struct. Dyn. 2015, 44, 1863-1879. [CrossRef]

52. Argyroudis, S.; Monge, O.; Finazzi, D.; Pessina, V. Vulnerability Assessment of Lifelines and Essential Facilities: Methodological Handbook; Appendix 1: Roadway Transportation System, Risk-UE Proj. Deliv. Report n GTR-RSK 0101-152av7; Publications Office of the European Union: Luxembourg, 2013.

53. Argyroudis, S.; Pitilakis, K. Seismic fragility curves of shallow tunnels in alluvial deposits. Soil Dyn. Earthq. Eng. 2012, 35, 1-12. [CrossRef]

54. Nielson, B.G.; DesRoches, R. Analytical seismic fragility curves for typical bridges in the central and southeastern United States. Earthq. Spectra 2007, 23, 615-633. [CrossRef]

55. Padgett, J.E.; DesRoches, R. Retrofitted bridge fragility analysis for typical classes of multispan bridges. Earthq. Spectra 2009, 25, 117-141. [CrossRef]

56. Fhwa, U. Status of the Nation's Highways, Bridges, and Transit: Conditions and Performance; US Department of Transportation: Washington, DC, USA, 2006.

57. Dong, Y.; Frangopol, D.M.; Saydam, D. Sustainability of highway bridge networks under seismic hazard. J. Earthq. Eng. 2014, 18, 41-66. [CrossRef]

58. EN 1992-1. Eurocode 8: Design of Structures for Earthquake Resistance-Part 1: General Rules, Seismic Actions and Rules for Buildings; European Commitee for Standardization: Brussels, Belgium, 2004.

59. Strate, H.E.; Humstone, E.; McMahon, S.; Gibson, L.; Bender, B.D. Functional classification for multimodal planning. Transp. Res. Rec. 1997, 1606, 51-62. [CrossRef]

60. Fhwa, U. Addendum to the 1997 Federal Highway Cost Allocation Study Final Report; US Federal Highway Administration: Washington, DC, USA, 2000. 
61. Lauwers, D. Functional Road Categorization: New Concepts and Challenges Related to Traffic Safety, Traffic Managment and Urban Design: Reflections Based on Practices in Belgium Confronted with Some Eastern European Cases; Transportation and land use interaction; POLITECHNICA Press: Bucuresti, Romania, 2008; pp. 149-164.

62. Goto, A.; Nakamura, H. Functionally hierarchical road classification considering the area characteristics for the performanceoriented road planning. Transp. Res. Procedia 2016, 15, 732-748. [CrossRef]

63. Paraphantakul, C. Review of Worldwide Road Classification Systems. In Proceedings of the 9th National Transportation Conference, Bangkok, Thailand, 20-21 November 2014.

64. Gaca, S.; Kiec, M. Speed management for local and regional rural roads. Transp. Res. Procedia 2016, 14, 4170-4179. [CrossRef]

65. Adafer, S.; Bensaibi, M. Seismic vulnerability classification of roads. Energy Procedia 2017, 139, 624-630. [CrossRef]

66. Benedetto, A.; Chiavari, A. Flood risk: A new approach for roads vulnerability assessment. Wseas Trans. Environ. Dev. 2010, 6 , 457-467.

67. Alamanis, N. Failure of Slopes and Embankments Under Static and Seismic Loading. Am. Sci. Res. J. Eng. Technol. Sci. 2017, 35, 95-126.

68. Mitoulis, S.A. Challenges and opportunities for the application of integral abutment bridges in earthquake-prone areas: A review. Soil Dyn. Earthq. Eng. 2020, 135, 106183. [CrossRef]

69. Nazri, F.M.; Curves, F.F. Seismic Fragility Assessment for Buildings Due to Earthquake Excitation; Springer: Berlin, Germany, 2018.

70. Kassem, M.M.; Nazri, F.M.; Wei, L.J.; Tan, C.G.; Shahidan, S.; Zuki, S.S.M. Seismic fragility assessment for moment-resisting concrete frame with setback under repeated earthquakes. Asian J. Civ. Eng. 2019, 20, 465-477. [CrossRef]

71. Rossetto, T.; D'Ayala, D.; Ioannou, I.; Meslem, A. Evaluation of existing fragility curves. In SYNER-G: Typology Definition and Fragility Functions for Physical Elements at Seismic Risk; Springer: Berlin, Germany, 2014; pp. 47-93.

72. HAZUS-MH, N. Users's Manual and Technical Manuals; Report Prepared for the Federal Emergency Management Agency; National Institute of Building sciences, Federal Emergency Management Agency (FEMA): Washington, DC, USA, 2004.

73. Giovinazzi, S.; King, A. Estimating Seismic Impacts on Lifelines: An International Review for RiskScape; University of Canterbury, Civil and Natural Resources Engineering: Christchurch, New Zealand, 2009.

74. Oblak, A.; Kuder, S.; Logar, J.; Da Fonseca, A.V. Numerical assessment of fragility curves for embankments on liquefiable ground. In Proceedings of the XVII ECSMGE-2019, Reykyavik, Iceland, 1-7 September 2019.

75. Kim, J.J. Development of empirical fragility curves in earthquake engineering considering nonspecific damage information. Adv. Civ. Eng. 2018, 2018, 1-13. [CrossRef]

76. Argyroudis, S.; Kaynia, A.M.; Pitilakis, K. Development of fragility functions for geotechnical constructions: Application to cantilever retaining walls. Soil Dyn. Earthq. Eng. 2013, 50, 106-116. [CrossRef]

77. Silva, V.; Akkar, S.; Baker, J.; Bazzurro, P.; Castro, J.M.; Crowley, H.; Dolsek, M.; Galasso, C.; Lagomarsino, S.; Monteiro, R.; et al. Current challenges and future trends in analytical fragility and vulnerability modeling. Earthq. Spectra 2019, 35, 1927-1952. [CrossRef]

78. Choudhury, T.; Kaushik, H.B. Treatment of uncertainties in seismic fragility assessment of RC frames with masonry infill walls. Soil Dyn. Earthq. Eng. 2019, 126, 105771. [CrossRef]

79. Panchireddi, B.; Ghosh, J. Cumulative vulnerability assessment of highway bridges considering corrosion deterioration and repeated earthquake events. Bull. Earthq. Eng. 2019, 17, 1603-1638. [CrossRef]

80. Park, Y.-J.; Ang, A.H.-S. Mechanistic seismic damage model for reinforced concrete. J. Struct. Eng. 1985, 111, 722-739. [CrossRef]

81. Colombo, A.; Negro, P. A damage index of generalised applicability. Eng. Struct. 2005, 27, 1164-1174. [CrossRef]

82. Huang, Q.; Gardoni, P.; Hurlebaus, S. A probabilistic damage detection approach using vibration-based nondestructive testing. Struct. Saf. 2012, 38, 11-21. [CrossRef]

83. Ghosh, J.; Padgett, J.E.; Sánchez-Silva, M. Seismic damage accumulation in highway bridges in earthquake-prone regions. Earthq. Spectra 2015, 31, 115-135. [CrossRef]

84. Baker, J.W. Efficient analytical fragility function fitting using dynamic structural analysis. Earthq. Spectra 2015, 31, 579-599. [CrossRef]

85. Lu, D.; Tighe, S.L.; Xie, W.-C. Pavement risk assessment for future extreme precipitation events under climate change. Transp. Res. Rec. 2018, 2672, 122-131. [CrossRef]

86. Calvi, G.M.; Pinho, R.; Magenes, G.; Bommer, J.J.; Restrepo-Vélez, L.F.; Crowley, H. Development of seismic vulnerability assessment methodologies over the past 30 years. Iset J. Earthq. Technol. 2006, 43, 75-104.

87. Winter, M.; Smith, J.; Fotopoulou, S.; Pitilakis, K.; Mavrouli, O.; Corominas, J.; Argyroudis, S. An expert judgement approach to determining the physical vulnerability of roads to debris flow. Bull. Eng. Geol. Environ. 2014, 73, 291-305. [CrossRef]

88. FEMA. NEHRP Recommended Seismic Provisions for New Buildings and Other Structures (FEMA P-750); U.S. Department of Homeland Security By the Building Seismic Safety Council of the National Institute of Building Science: Washington, DC, USA, 2009.

89. Werner, S.D.; Taylor, C.E.; Cho, S.; Lavoie, J.-P.; Huyck, C.K.; Eitzel, C.; Chung, H.; Eguchi, R.T. Redars 2 Methodology and Software for Seismic Risk Analysis of Highway Systems; US Department of Transportation Federal Highway Administration: Washington, DC, USA, 2006.

90. Rojahn, C.; Sharpe, R.L. Earthquake Damage Evaluation Data for California; Applied Technology Council: Redwood City, CA, USA, 1985. 
91. Muntasir Billah, A.; Shahria Alam, M. Seismic fragility assessment of highway bridges: A state-of-the-art review. Struct. Infrastruct. Eng. 2015, 11, 804-832. [CrossRef]

92. Andreotti, G.; Lai, C.G. Use of fragility curves to assess the seismic vulnerability in the risk analysis of mountain tunnels. Tunn. Undergr. Space Technol. 2019, 91, 103008. [CrossRef]

93. Porter, K. A beginner's guide to fragility, vulnerability, and risk. Encycl. Earthq. Eng. 2015, 2015, $235-260$.

94. Maruyama, Y.; Yamazaki, F.; Mizuno, K.; Yogai, H.; Tsuchiya, Y. In Development of Fragility Curves for Highway Embankment Based on Damage Data from Recent Earthquakes in Japan. In Proceedings of the 14th World Conference on Earthquake Engineering, Beijing, China, 12-17 October 2008; p. 8.

95. Stefanidou, S.P.; Kappos, A.J. Methodology for the development of bridge-specific fragility curves. Earthq. Eng. Struct. Dyn. 2017, 46, 73-93. [CrossRef]

96. Argyroudis, S.; Tsinidis, G.; Gatti, F.; Pitilakis, K. Effects of SSI and lining corrosion on the seismic vulnerability of shallow circular tunnels. Soil Dyn. Earthq. Eng. 2017, 98, 244-256. [CrossRef]

97. Qiu, J.; Liu, H.; Lai, J.; Lai, H.; Chen, J.; Wang, K. Investigating the long-term settlement of a tunnel built over improved loessial foundation soil using jet grouting technique. J. Perform. Constr. Facil. 2018, 32, 04018066. [CrossRef]

98. Kilanitis, I.; Sextos, A. Integrated seismic risk and resilience assessment of roadway networks in earthquake prone areas. Bull. Earthq. Eng. 2019, 17, 181-210. [CrossRef]

99. Santarelli, S.; Bernardini, G.; Quagliarini, E.; D’Orazio, M. New indices for the existing city-centers streets network reliability and availability assessment in earthquake emergency. Int. J. Archit. Herit. 2018, 12, 153-168. [CrossRef]

100. Francini, M.; Gaudio, S.; Palermo, A.; Viapiana, M.F. A performance-based approach for innovative emergency planning. Sustain. Cities Soc. 2020, 53, 101906. [CrossRef]

101. Elnashai, A.S.; Borzi, B.; Vlachos, S. Deformation-based vulnerability functions for RC bridges. Struct. Eng. Mech. 2004, 17, 215-244. [CrossRef]

102. Zanini, M.A.; Pellegrino, C.; Morbin, R.; Modena, C. Seismic vulnerability of bridges in transport networks subjected to environmental deterioration. Bull. Earthq. Eng. 2013, 11, 561-579. [CrossRef]

103. Djemai, M.; Bensaibi, M.; Zellat, K. Seismic Vulnerability Assessment of Bridges Using Analytical Hierarchy Process; IOP Conference Series: Materials Science and Engineering; IOP Publishing: Bristol, UK, 2019; p. 012106.

104. Teknomo, K. Analytic Hierarchy Process (AHP) Tutorial. 2006. Available online: https://people.revoledu.com/kardi/tutorial/ AHP / (accessed on 18 September 2020).

105. Corominas, J.; van Westen, C.; Frattini, P.; Cascini, L.; Malet, J.-P.; Fotopoulou, S.; Catani, F.; Van Den Eeckhaut, M.; Mavrouli, O.; Agliardi, F. Recommendations for the quantitative analysis of landslide risk. Bull. Eng. Geol. Environ. 2014, 73, 209-263. [CrossRef]

106. Titko, M.; Zagorecki, A. Modelling vulnerability of transportation network using influence diagrams. Commun.-Sci. Lett. Univ. Zilina 2013, 15, 58-62.

107. Meyer, M.D. Transportation Planning Handbook; John Wiley \& Sons: Hoboken, NJ, USA, 2016.

108. Kilanitis, I.; Sextos, A. Impact of earthquake-induced bridge damage and time evolving traffic demand on the road network resilience. J. Traffic Transp. Eng. 2019, 6, 35-48. [CrossRef]

109. Merschman, E.; Doustmohammadi, M.; Salman, A.M.; Anderson, M. Postdisaster decision framework for bridge repair prioritization to improve road network resilience. Transp. Res. Rec. 2020, 2674, 81-92. [CrossRef]

110. Zhang, X.; Miller-Hooks, E.; Denny, K. Assessing the role of network topology in transportation network resilience. J. Transp. Geogr. 2015, 46, 35-45. [CrossRef]

111. Wang, X.; You, S.; Wang, L. Classifying road network patterns using multinomial logit model. J. Transp. Geogr. 2017, 58, 104-112. [CrossRef]

112. Zanin, M.; Sun, X.; Wandelt, S. Studying the topology of transportation systems through complex networks: Handle with care. J. Adv. Transp. 2018, 2018, 3156137. [CrossRef]

113. Sohouenou, P.Y.; Christidis, P.; Christodoulou, A.; Neves, L.A.; Presti, D.L. Using a random road graph model to understand road networks robustness to link failures. Int. J. Crit. Infrastruct. Prot. 2020, 29, 100353. [CrossRef]

114. Taylor, M.A. Critical transport infrastructure in Urban areas: Impacts of traffic incidents assessed using accessibility-based network vulnerability analysis. Growth Chang. 2008, 39, 593-616. [CrossRef]

115. Berdica, K. An introduction to road vulnerability: What has been done, is done and should be done. Transp. Policy 2002, 9, 117-127. [CrossRef]

116. D'este, G.A.; Taylor, M.A. Network Vulnerability: An Approach to Reliability Analysis at the Level of National Strategic Transport Networks; Emerald Group Publishing Limited: Bingley, UK, 2003.

117. Chang, S.E. Transportation planning for disasters: An accessibility approach. Environ. Plan. A 2003, 35, 1051-1072. [CrossRef]

118. Davidson, K.B. Accessibility in transport/land-use modelling and assessment. Environ. Plan. A 1977, 9, 1401-1416. [CrossRef]

119. Black, J.; Conroy, M. Accessibility measures and the social evaluation of urban structure. Environ. Plan. A 1977, 9, $1013-1031$. [CrossRef]

120. Maltinti, F.; Melis, D.; Annunziata, F. Road network vulnerability: A review of the literature. In ICSDC 2011: Integrating Sustainability Practices in the Construction Industry; American Society of Civil Engineers: Reston, VA, USA, 2012 ; pp. 677-685. 
121. Luathep, P.; Sumalee, A.; Ho, H.; Kurauchi, F. Large-scale road network vulnerability analysis: A sensitivity analysis based approach. Transportation 2011, 38, 799-817. [CrossRef]

122. Hansen, W.G. How accessibility shapes land use. J. Am. Inst. Plan. 1959, 25, 73-76. [CrossRef]

123. Ertugay, K.; Argyroudis, S.; Düzgün, H.Ş. Accessibility modeling in earthquake case considering road closure probabilities: A case study of health and shelter service accessibility in Thessaloniki, Greece. Int. J. Disaster Risk Reduct. 2016, 17, 49-66. [CrossRef]

124. Lotfi, S.; Koohsari, M.J. Measuring objective accessibility to neighborhood facilities in the city (A case study: Zone 6 in Tehran, Iran). Cities 2009, 26, 133-140. [CrossRef]

125. Vahidnia, M.H.; Alesheikh, A.A.; Alimohammadi, A. Hospital site selection using fuzzy AHP and its derivatives. J. Environ. Manag. 2009, 90, 3048-3056. [CrossRef]

126. Kondrateva, E.; Sidorov, A.; Saprykin, O. An Isochrones Based Public Transport stops Optimization Technique. In Proceedings of the 2017 5th IEEE International Conference on Models and Technologies for Intelligent Transportation Systems (MT-ITS), Napoli, Italy, 26-28 June 2017; pp. 182-187.

127. Allen, J. Using network segments in the visualization of urban isochrones. Cartogr. Int. J. Geogr. Inf. Geovisualization 2018, 53, 262-270. [CrossRef]

128. Messina, J.P.; Shortridge, A.M.; Groop, R.E.; Varnakovida, P.; Finn, M.J. Evaluating Michigan's community hospital access: Spatial methods for decision support. Int. J. Health Geogr. 2006, 5, 42. [CrossRef] [PubMed]

129. Yang, D.-H.; Goerge, R.; Mullner, R. Comparing GIS-based methods of measuring spatial accessibility to health services. J. Med. Syst. 2006, 30, 23-32. [CrossRef] [PubMed]

130. Ertugay, K.; Duzgun, S. GIS-based stochastic modeling of physical accessibility using GPS-based floating car data and Monte Carlo simulation. Int. J. Geogr. Inf. Sci. 2011, 25, 1491-1506. [CrossRef]

131. Delamater, P.L.; Messina, J.P.; Shortridge, A.M.; Grady, S.C. Measuring geographic access to health care: Raster and network-based methods. Int. J. Health Geogr. 2012, 11, 15. [CrossRef] [PubMed]

132. Halden, D.; Mcguigan, D.; Nisbet, A.; Mckinnon, A. Accessibility: Review of Measuring Techniques and Their Application; Great Britain, Scottish Executive, Central Research Unit: Edinburgh, UK, 2000.

133. Balijepalli, C.; Oppong, O. Measuring vulnerability of road network considering the extent of serviceability of critical road links in urban areas. J. Transp. Geogr. 2014, 39, 145-155. [CrossRef]

134. Zhang, Z.; Zhu, M.; Ban, J.; Zhang, Y. A verification method for identifying critical segments considering highly correlated characteristics of traffic flow. Int. J. Mod. Phys. C 2020, 31, 1-13. [CrossRef]

135. Taylor, M.A.; Sekhar, S.V.; D’Este, G.M. Application of accessibility based methods for vulnerability analysis of strategic road networks. Netw. Spat. Econ. 2006, 6, 267-291. [CrossRef]

136. Nagurney, A.; Qiang, Q. A Transportation Network Efficiency Measure that Captures Flows, Behavior, and Costs with Applications to Network Component Importance Identification and Vulnerability. In Proceedings of the POMS 18th Annual Conference, Dallas, TX, USA, 4-7 May 2007.

137. Jenelius, E.; Petersen, T.; Mattsson, L.-G. Importance and exposure in road network vulnerability analysis. Transp. Res. Part. A 2006, 40, 537-560. [CrossRef]

138. Scott, D.M.; Novak, D.C.; Aultman-Hall, L.; Guo, F. Network robustness index: A new method for identifying critical links and evaluating the performance of transportation networks. J. Transp. Geogr. 2006, 14, 215-227. [CrossRef]

139. Allen, J.; Browne, M.; Woodburn, A. London Freight Data Report: 2014 Update; Transport for London: London, UK, 2014.

140. Rupi, F.; Bernardi, S.; Rossi, G.; Danesi, A. The evaluation of road network vulnerability in mountainous areas: A case study. Netw. Spat. Econ. 2015, 15, 397-411. [CrossRef]

141. Gecchele, G.; Ceccato, R.; Gastaldi, M. Road Network Vulnerability Analysis: Case Study Considering Travel Demand and Accessibility Changes. J. Transp. Eng. Part. A 2019, 145, 05019004. [CrossRef]

142. Chen, B.Y.; Lam, W.H.; Sumalee, A.; Li, Q.; Li, Z.-C. Vulnerability analysis for large-scale and congested road networks with demand uncertainty. Transp. Res. Part. A 2012, 46, 501-516. [CrossRef]

143. Latora, V.; Marchiori, M. Efficient behavior of small-world networks. Phys. Rev. Lett. 2001, 87, 198701. [CrossRef] [PubMed]

144. Li, F.; Jia, H.; Luo, Q.; Li, Y.; Yang, L. Identification of critical links in a large-scale road network considering the traffic flow betweenness index. PLOS ONE 2020, 15, e0227474.

145. Rehak, D.; Patrman, D.; Brabcová, V.; Dvořák, Z. Identifying critical elements of road infrastructure using cascading impact assessment. Transport 2020, 35, 1-15. [CrossRef]

146. Vodák, R.; Bíl, M.; Svoboda, T.; Křivánková, Z.; Kubeček, J.; Rebok, T.; Hliněný, P. A deterministic approach for rapid identification of the critical links in networks. PLoS ONE 2019, 14, e0219658. [CrossRef]

147. Eidsvig, U.; Tanasic, N.; Hajdin, R.; Ekeheien, C.; Piciullo, L. Vulnerability of Terrestrial Transportation Lines to Natural Events; EGU General Assembly Conference Abstracts; EGU General Assembly: Lund, Sweden, 2020; p. 9542.

148. Liu, C.; Fan, Y.; Ordóñez, F. A two-stage stochastic programming model for transportation network protection. Comput. Oper. Res. 2009, 36, 1582-1590. [CrossRef]

149. Bocchini, P.; Frangopol, D.M. Connectivity-based optimal scheduling for maintenance of bridge networks. J. Eng. Mech. 2013, 139, 760-769. [CrossRef]

150. Tang, Y.; Huang, S. Assessing seismic vulnerability of urban road networks by a Bayesian network approach. Transp. Res. Part D 2019, 77, 390-402. [CrossRef] 
151. Bayraktarli, Y.Y.; Ulfkjaer, J.-P.; Yazgan, U.; Faber, M.H. On the application of Bayesian probabilistic networks for earthquake risk management. In Proceedings of the 9th International Conference on Structural Safety and Reliability (ICOSSAR 05), Rome, Italy, 19-23 June 2005; pp. 20-23.

152. Bensi, M.T.; Der Kiureghian, A.; Straub, D. A Bayesian Network Methodology for Infrastructure Seismic Risk Assessment and Decision Support. Ph.D. Thesis, University of California, Berkley, CA, USA, 2011.

153. Khakzad, N.; Khan, F.; Amyotte, P. Safety analysis in process facilities: Comparison of fault tree and Bayesian network approaches. Reliab. Eng. Syst. Saf. 2011, 96, 925-932. [CrossRef]

154. Costa, C.; Figueiredo, R.; Silva, V.; Bazzurro, P. Application of open tools and datasets to probabilistic modeling of road traffic disruptions due to earthquake damage. Earthq. Eng. Struct. Dyn. 2020, 49, 1236-1255. [CrossRef]

155. Jun-Qiang, L.; Long-Hai, Y.; Liu, W.-Y.; Zhao, L. Measuring road network vulnerability with sensitivity analysis. PLoS ONE 2017, 12, e0170292. [CrossRef] [PubMed]

156. Bell, M.G. The estimation of an origin-destination matrix from traffic counts. Transp. Sci. 1983, 17, 198-217. [CrossRef]

157. Jin, L.; Wang, H.; Xie, B.; Yu, L.; Liu, L. A user exposure based approach for non-structural road network vulnerability analysis. PLoS ONE 2017, 12, e0188790. [CrossRef]

158. Khademi, N.; Balaei, B.; Shahri, M.; Mirzaei, M.; Sarrafi, B.; Zahabiun, M.; Mohaymany, A.S. Transportation network vulnerability analysis for the case of a catastrophic earthquake. Int. J. Disaster Risk Reduct. 2015, 12, 234-254. [CrossRef]

159. Liu, M.; Agarwal, J.; Blockley, D. Vulnerability of road networks. Civ. Eng. Environ. Syst. 2016, 33, 147-175. [CrossRef]

160. Cai, H.; Zhu, J.; Yang, C.; Fan, W.; Xu, T. Vulnerability analysis of metro network incorporating flow impact and capacity constraint after a disaster. J. Urban. Plan. Dev. 2017, 143, 04016031. [CrossRef]

161. Bíl, M.; Vodák, R.; Kubeček, J.; Bílová, M.; Sedoník, J. Evaluating road network damage caused by natural disasters in the Czech Republic between 1997 and 2010. Transp. Res. Part. A Policy Pract. 2015, 80, 90-103.

162. Caiado, G.; Oliveira, C.; Ferreira, M.A.; Sá, F. Assessing urban road network seismic vulnerability: An integrated approach. In Proceedings of the 15WCEE, Lisbon, Portugal, 24-28 September 2012.

163. Clarke, J.; Lam, J.C.; Gehl, P.; Taalab, K.; Corbally, R. Risk assessment for an Italian road network due to an extreme earthquake hazard scenario and the associated landslide cascading effects. In Proceedings of the Civil Engineering Research in Ireland (CERI2016), Galway, Ireland, 29-30 August 2016.

164. Toyfur, M.F.; Pribadi, K.S. Seismic risk assessment for road in Indonesia. In AIP Conference Proceedings; AIP Publishing LLC: Melville, NY, USA, 2016; p. 030006.

165. Zanini, M.A.; Faleschini, F.; Zampieri, P.; Pellegrino, C.; Gecchele, G.; Gastaldi, M.; Rossi, R. Post-quake urban road network functionality assessment for seismic emergency management in historical centres. Struct. Infrastruct. Eng. 2017, 13, 1117-1129. [CrossRef]

166. Chamorro, A.; Echaveguren, T.; Allen, E.; Contreras, M.; Dagá, J.; de Solminihac, H.; Lara, L.E. Sustainable Risk Management of Rural Road Networks Exposed to Natural Hazards: Application to Volcanic Lahars in Chile. Sustainability 2020, 12, 6774. [CrossRef]

167. Shinozuka, M.; Murachi, Y.; Dong, X.; Zhou, Y.; Orlikowski, M.J. Effect of seismic retrofit of bridges on transportation networks. Earthq. Eng. Eng. Vib. 2003, 2, 169-179. [CrossRef]

168. Duzgun, H.; Yucemen, M.; Kalaycioglu, H.; Celik, K.; Kemec, S.; Ertugay, K.; Deniz, A. An integrated earthquake vulnerability assessment framework for urban areas. Nat. Hazards 2011, 59, 917-947. [CrossRef]

169. Yang, D.Y.; Frangopol, D.M. Risk-Based Vulnerability Analysis of Deteriorating Coastal Bridges under Hurricanes Considering Deep Uncertainty of Climatic and Socioeconomic Changes. Asce-Asme J. Risk Uncertain. Eng. Syst. Part A 2020, 6, 04020032. [CrossRef]

170. Kiremidjian, A.; Moore, J.; Fan, Y.Y.; Yazlali, O.; Basoz, N.; Williams, M. Seismic risk assessment of transportation network systems. J. Earthq. Eng. 2007, 11, 371-382. [CrossRef]

171. Rus, K.; Kilar, V.; Koren, D. Resilience assessment of complex urban systems to natural disasters: A new literature review. Int. J. Disaster Risk Reduct. 2018, 31, 311-330. [CrossRef]

172. Sevilla, I.; Chrobocinski, P.; Barmpas, F.; Schmidt, F.; Kerle, N.; Kostaridis, A.; Doulamis, A.; Russotto, R. Improving Resilience of Transport Instrastructure to Climate Change and other natural and Manmande events based on the combined use of Terrestrial and Airbone Sensors and Advanced Modelling Tools. In Proceedings of the CONAMA 2018, Madrid, Spain, $26-29$ November 2018.

173. Bacciu, D.; Carta, A.; Gnesi, S.; Semini, L. An experience in using machine learning for short-term predictions in smart transportation systems. J. Log. Algebraic Methods Program. 2017, 87, 52-66. [CrossRef]

174. Serrano, W. Deep Reinforcement Learning Algorithms in Intelligent Infrastructure. Infrastructures 2019, 4, 52. [CrossRef]

175. Zantalis, F.; Koulouras, G.; Karabetsos, S.; Kandris, D. A review of machine learning and IoT in smart transportation. Future Internet 2019, 11, 94. [CrossRef]

176. Ramamoorthy, S.; Kowsigan, M.; Balasubramanie, P.; Paul, P.J. Smart City Infrastructure Management System Using IoT. Role Edge Anal. Sustain. Smart City Dev. Chall. Solut. 2020, 127-138.

177. Van Noort, M.; van Arem, B.; Park, B. MOBYSIM: An integrated traffic simulation platform. In Proceedings of the 13th International IEEE Conference on Intelligent Transportation Systems, Madeira Island, Portugal, 19-22 September 2010; pp. 1301-1306. 